\title{
Organic matter sources, fluxes and greenhouse gas exchange in the Oubangui River (Congo River basin)
}

\author{
S. Bouillon ${ }^{1}$, A. Yambélée ${ }^{2}$, R. G. M. Spencer ${ }^{3}$, D. P. Gillikin ${ }^{4}$, P. J. Hernes ${ }^{5}$, J. Six ${ }^{6}$, R. Merckx ${ }^{1}$, and A. V. Borges \\ ${ }^{1}$ Department Earth and Environmental Sciences, K.U. Leuven, Leuven, Belgium \\ ${ }^{2}$ Service de l'Agrométéorologie et de Climatologie, Direction de la Météorologie Nationale, Bangui, Central African \\ Republic \\ ${ }^{3}$ Woods Hole Research Center, 149 Woods Hole Road, Falmouth, Massachusetts, 02540, USA \\ ${ }^{4}$ Department of Geology, Union College, Schenectady, NY, USA \\ ${ }^{5}$ Department of Land, Air, and Water Resources, University of California, One Shields Avenue, Davis, CA 95616, USA \\ ${ }^{6}$ Department of Plant Sciences, University of California, Davis, One Shields Ave, California, 95616, USA \\ ${ }^{7}$ University of Liège, Chemical Oceanography Unit, Liège, Belgium
}

Correspondence to: S. Bouillon (steven.bouillon@ees.kuleuven.be)

Received: 16 December 2011 - Published in Biogeosciences Discuss.: 3 January 2012

Revised: 11 May 2012 - Accepted: 14 May 2012 - Published: 8 June 2012

\begin{abstract}
The Oubangui is a major tributary of the Congo River, draining an area of $\sim 500000 \mathrm{~km}^{2}$ mainly consisting of wooded savannahs. Here, we report results of a one year long, 2-weekly sampling campaign in Bangui (Central African Republic) since March 2010 for a suite of physicochemical and biogeochemical characteristics, including total suspended matter (TSM), bulk concentration and stable isotope composition of particulate organic carbon (POC and $\left.\delta^{13} \mathrm{C}_{\mathrm{POC}}\right)$, particulate nitrogen ( $\mathrm{PN}$ and $\delta^{15} \mathrm{~N}_{\mathrm{PN}}$ ), dissolved organic carbon (DOC and $\delta^{13} \mathrm{C}_{\mathrm{DOC}}$ ), dissolved inorganic carbon (DIC and $\delta^{13} \mathrm{C}_{\mathrm{DIC}}$ ), dissolved greenhouse gases $\left(\mathrm{CO}_{2}, \mathrm{CH}_{4}\right.$ and $\left.\mathrm{N}_{2} \mathrm{O}\right)$, and dissolved lignin composition. $\delta^{13} \mathrm{C}$ signatures of both POC and DOC showed strong seasonal variations $(-30.6$ to $-25.8 \%$ o, and -31.8 to $-27.1 \%$, respectively), but their different timing indicates that the origins of POC and DOC may vary strongly over the hydrograph and are largely uncoupled, differing up to $6 \%$ in $\delta^{13} \mathrm{C}$ signatures. Dissolved lignin characteristics (carbon-normalised yields, cinnamyl:vanillyl phenol ratios, and vanillic acid to vanillin ratios) showed marked differences between high and low discharge conditions, consistent with major seasonal variations in the sources of dissolved organic matter. We observed a strong seasonality in $p \mathrm{CO}_{2}$, ranging between $470 \pm 203 \mathrm{ppm}$ for $Q<1000 \mathrm{~m}^{3} \mathrm{~s}^{-1}$ $(n=10)$ to a maximum of $3750 \mathrm{ppm}$ during the first stage of the rising discharge. The low $\mathrm{POC} / \mathrm{PN}$ ratios, high \% $\mathrm{POC}$
\end{abstract}

and low and variable $\delta^{13} \mathrm{C}_{\mathrm{POC}}$ signatures during low flow conditions suggest that the majority of the POC pool during this period consists of in situ produced phytoplankton, consistent with concurrent $p \mathrm{CO}_{2}$ (partial pressure of $\mathrm{CO}_{2}$ ) values only slightly above and, occasionally, below atmospheric equilibrium. Water-atmosphere $\mathrm{CO}_{2}$ fluxes estimated using two independent approaches averaged 105 and $204 \mathrm{~g} \mathrm{C} \mathrm{m}^{-2} \mathrm{yr}^{-1}$, i.e. more than an order of magnitude lower than current estimates for large tropical rivers globally. Although tropical rivers are often assumed to show much higher $\mathrm{CO}_{2}$ effluxes compared to temperate systems, we show that in situ production may be high enough to dominate the particulate organic carbon pool, and lower $p \mathrm{CO}_{2}$ values to near equilibrium values during low discharge conditions. The total annual flux of TSM, POC, PN, DOC and DIC are $2.33 \mathrm{Tg} \mathrm{yr}^{-1}, 0.14 \mathrm{Tg} \mathrm{C} \mathrm{yr}^{-1}, 0.014 \mathrm{Tg} \mathrm{N} \mathrm{yr}^{-1}$, $0.70 \mathrm{TgC}_{\mathrm{yr}}{ }^{-1}$, and $0.49 \mathrm{TgC} \mathrm{yr}^{-1}$, respectively. While our TSM and POC fluxes are similar to previous estimates for the Oubangui, DOC fluxes were $\sim 30 \%$ higher and bicarbonate fluxes were $\sim 35 \%$ lower than previous reports. DIC represented $58 \%$ of the total annual $\mathrm{C}$ flux, and under the assumptions that carbonate weathering represents $25 \%$ of the DIC flux and that $\mathrm{CO}_{2}$ from respiration drives chemical weathering, this flux is equivalent to $\sim 50 \%$ of terrestrial-derived riverine $\mathrm{C}$ transport. 


\section{Introduction}

During the past decade, the role of rivers in regional and global carbon (C) budgets has received an increasing amount of attention. In particular, the focus has shifted from solely quantifying transport fluxes towards better constraining the cycling of $\mathrm{C}$ within river systems, and understanding the variability in the sources and age of riverine C. Given the generally heterotrophic nature of rivers and their oversaturation in $\mathrm{CO}_{2}$ with respect to atmospheric equilibrium (Cole and Caraco, 2001a; Duarte and Prairie, 2005; Butman and Raymond, 2011), it is recognized that $\mathrm{C}$ inputs from the terrestrial environment are not only transported by rivers, but that a significant fraction of these lateral inputs are remineralized and returned to the atmosphere as $\mathrm{CO}_{2}$, or deposited in reservoirs and floodplains (e.g. Battin et al., 2008; Aufdenkampe et al., 2011). Global C budgets often distinguish terrestrial and marine sinks and sources, with freshwater ecosystems, estuaries and other coastal ecosystems often being neglected or ambiguously interwoven in such estimates. Given the similar order of magnitude of lateral $\mathrm{C}$ inputs in river systems (at least $1.9 \mathrm{Pg} \mathrm{Cyr}^{-1}$ according to Cole et al. (2007) but some recent estimates are $>3 \mathrm{Pg} \mathrm{C} \mathrm{yr}^{-1}$, Aufdenkampe et al., 2011) and global net ecosystem production for the terrestrial biosphere $\left(\sim 2 \mathrm{PgC} \mathrm{yr}^{-1}\right)$, better constraining the role of river networks in the $\mathrm{C}$ cycle is a challenge and prerequisite to improve our understanding of regional and global C dynamics (Richey et al., 2009; Butman and Raymond, 2011).

Inputs of both particulate and dissolved material are strongly linked to land-use changes and catchment characteristics, such as climate, vegetation, topography and soil types - causing some regions to be disproportionally important in sediment or solute fluxes. For example, the Indo-Pacific region is recognized for its role in sediment and $\mathrm{C}$ delivery to the ocean (Milliman and Svytski, 1992; Lyons et al., 2002; Bird et al., 2008), and $\sim 60 \%$ of the global riverine $\mathrm{C}$ transport is thought to occur in the tropical zone (Ludwig et al., 1996; Schlünz and Schneider, 2000). Tropical aquatic ecosystems have also been suggested to show higher $\mathrm{CO}_{2}$ evasion rates than their temperate counterparts, both for lakes (e.g. Marotta et al., 2009) and river systems (Aufdenkampe et al., 2011). While temperature indeed increases microbial metabolism (e.g. Gudasz et al., 2010), it is questionable as to whether the current empirical database is sufficiently large and unbiased to support general statements concerning contrasts in $\mathrm{CO}_{2}$ evasion between temperate and tropical systems.

The Congo River basin is the 2nd largest in the world in terms of discharge and catchment size $\left(3.8 \times 10^{6} \mathrm{~km}^{2}\right)$, and has been estimated to transport between 13.4 and 14.4 $\mathrm{Pg} \mathrm{Cyr}^{-1}$ of organic $\mathrm{C}$ to the Atlantic Ocean, $85-90 \%$ of which is in the form of dissolved organic carbon (DOC) (Coynel et al., 2005; Seyler et al., 2005). Sediment fluxes in the Congo basin, however, are generally low compared to other tropical systems (Coynel et al., 2005). The biogeo- chemistry of the Congo basin is relatively poorly studied in comparison to the Amazon, where a variety of studies over the past three decades have provided a wealth of information into the sources, age, and processing of $\mathrm{C}$ in river systems (e.g. Richey et al., 1990, 2002; Mayorga et al., 2005). A number of sampling programmes have produced extensive data on major and trace element and bicarbonate fluxes (e.g. Nkounkou and Probst, 1987; Probst et al., 1992, 1994; Seyler and Elbaz-Poulichet, 1996), as well as sediment and organic C flux data (Coynel et al., 2005; Seyler et al., 2005; Laraque et al., 2009) for a limited number of locations, both on the main Congo River and in some of its major tributaries such as the Oubangui and Sangha. The majority of data stem from the 1980's and 1990's, but recent anthropogenic or climatic changes (land use, population pressure, precipitation, ...) could have modified some of the riverine fluxes. Moreover, more detailed geochemical analyses on organic matter or $\mathrm{C}$ cycling in the Congo river network have only recently been employed (Mariotti et al., 1991; Gadel et al., 1993; Stubbins et al., 2010; Spencer et al., 2009, 2010a, 2012).

Starting in March 2010, we have re-initiated regular sampling on the Oubangui, one of the main tributaries of the Congo River. First, a more intensive sampling resolution was adopted (2-weekly versus existing monthly datasets) to improve flux calculations. Second, a wider range of parameters and proxies were analysed, allowing not only quantification of riverine transport of key elements, but also examination of seasonality in $\mathrm{C}$ sources and greenhouse gas exchange $\left(\mathrm{CO}_{2}\right.$, $\mathrm{CH}_{4}, \mathrm{~N}_{2} \mathrm{O}$ ) with the atmosphere. Proxies used here for the first time on the Oubangui River include stable carbon isotope measurements $\left(\delta^{13} \mathrm{C}\right)$ on both DIC, DOC, and POC, and the composition of dissolved lignin phenols. $\delta^{13} \mathrm{C}$ signatures are potentially powerful tracers of the origin and cycling of $\mathrm{C}$ in rivers, in particular in settings where the vegetation may consist of both $\mathrm{C} 3$ and $\mathrm{C} 4$ vegetation - which differ strongly in their $\delta^{13} \mathrm{C}$ signatures. Lignin phenols are biopolymers that are powerful tracers of vascular plant derived organic $\mathrm{C}$ as they contain compositional characteristics that can be linked to source information and record biogeochemical processing (Spencer et al., 2010b). With respect to sourcing organic C, as syringyl phenols are solely found in angiosperms and cinnamyl phenols are only found in non-woody tissue, the ratios of these phenols to the ubiquitous vanillyl phenols can differentiate sources from angiosperm and gymnosperm plant types $(\mathrm{S}: \mathrm{V})$ and non-woody and woody tissues $(\mathrm{C}: \mathrm{V}$; Hedges and Mann, 1979), respectively. A number of studies have observed that as biogeochemical processing occurs, quantities of oxidized lignin phenols increase, leading to a higher yield of acidic phenols on $\mathrm{CuO}$ oxidation (Opsahl and Benner, 1995; Spencer et al., 2009). Therefore, assuming that no differential sorption occurs (Hernes et al., 2007), with certain caveats the acid:adelhyde ( $\mathrm{Ad}: \mathrm{Al})$ ratios of lignin phenols may be utilized to examine the relative degree of degradation of organic $\mathrm{C}$. 
This study represents a dataset with the highest temporal resolution and widest range of proxies on $\mathrm{C}$ cycling for any African river system to date. Finally, given decadal-scale trends reported for the Oubangui's annual discharge (Orange et al., 1997; Laraque et al., 2001), long-term flux datasets could be useful to examine changes in material transport related to discharge variations, whether natural or anthropogenically induced (e.g. Coe et al., 2009). Data from the continuation of our current monitoring work might therefore provide some clues into long-term changes in riverine material fluxes for the Oubangui catchment.

\section{Materials and methods}

\subsection{Oubangui catchment characteristics and hydrology}

The Oubangui river (Fig. 1) is the second largest tributary of the Congo River, with a length of $2400 \mathrm{~km}$ from the source (Uele River) to its confluence with the Congo River, and a drainage basin of $644000 \mathrm{~km}^{2}$, of which $489000 \mathrm{~km}^{2}$ (76\%) is located upstream of Bangui (Coynel et al., 2005). The Oubangui catchment upstream of Bangui is dominated by dry wooded savannahs, with more humid forest situated downstream towards the confluence with the Congo mainstem. The mean annual precipitation in the catchment is $\sim 1400$ $1540 \mathrm{~mm} \mathrm{yr}^{-1}$ (Laraque et al., 2001; Coynel et al., 2005). The hydrology of the Oubangui is characterized by a single main flood peak and maximum discharge typically in October-November. Mean annual discharge has fluctuated between $2120 \mathrm{~m}^{3} \mathrm{~s}^{-1}$ (1990) and $6110 \mathrm{~m}^{3} \mathrm{~s}^{-1}$ (1969). Several authors have suggested that, following a relatively wet period during the 1960's, the Oubangui and other catchments in the region have experienced a significant decrease in discharge since the 1980's (Orange et al., 1997; Laraque et al., 2001), although this is debated by others based on an analysis of the annual minimum and maximum discharge (Runge and Nguimalet, 2005). Although we did not find land-use data specifically for the Oubangui catchment, deforestation rates in the Central African Republic are reported to be among the lowest in Africa (net deforestation of $0.06 \% \mathrm{yr}^{-1}$, Duveiller et al., 2008). According to FAO statistics (http://faostat.fao. org/), agricultural land use has increased only $8 \%$ in the last 4 decades, and makes for $\sim 8 \%$ of the total land area. Considering a national population density of $\sim 7$ inhabitants $\mathrm{km}^{-2}$, these figures support classifying the Oubangui catchment as relatively pristine.

\subsection{Sampling and analytical techniques}

Monitoring on the Oubangui in Bangui (Central African Republic, $4^{\circ} 21^{\prime} \mathrm{N}, 18^{\circ} 34^{\prime} \mathrm{E}$ ) was initiated in late March 2010, and was followed by approximately 2 -weekly sampling. Data presented here cover the period of 20 March 2010 to 19 March 2011, covering a full year and a total of 28 sampling dates (for the first sampling date, data are an average

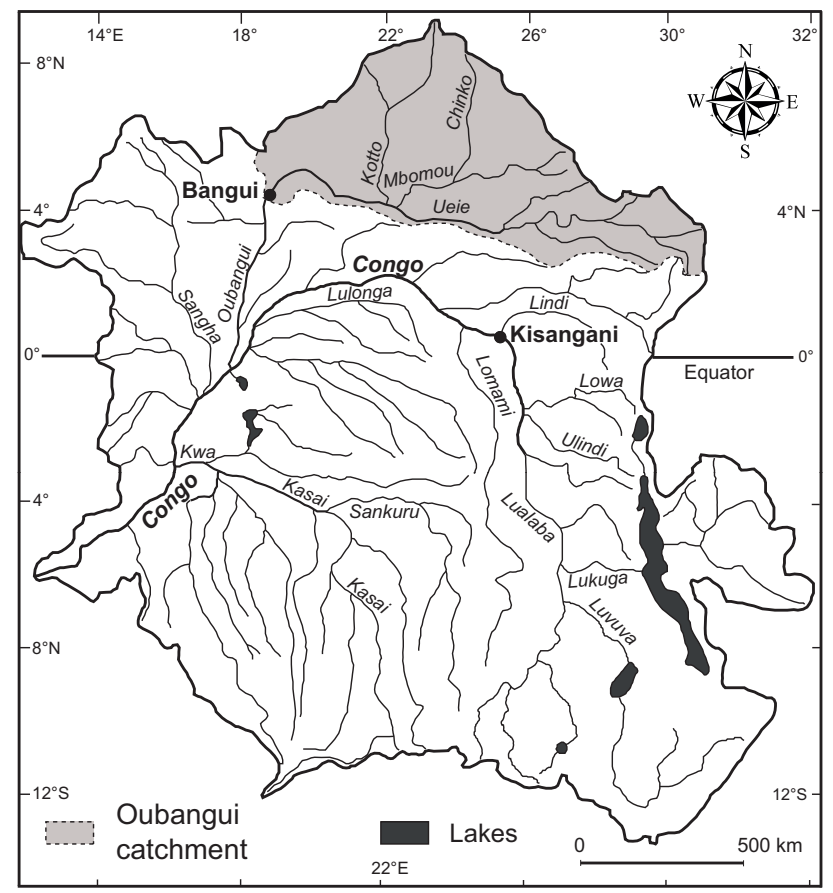

Fig. 1. Overview map of the Congo River drainage network, with indication of the sampling location and the extent of the Oubangui catchment upstream of the sampling site. Modified after Runge and Nguimalet (2005).

of 3 measurements). Water temperature, conductivity, dissolved oxygen $\left(\mathrm{O}_{2}\right)$ and $\mathrm{pH}$ were measured in situ with a YSI ProPlus multimeter, whereby the $\mathrm{O}_{2}$ and $\mathrm{pH}$ probes were calibrated on each day of data collection using water saturated air and United States National Bureau of Standards buffer solutions (4 and 7), respectively. All sampling was performed from dugout canoes in the middle section of the river, at $\sim 0.5 \mathrm{~m}$ below the water surface. Water levels fluctuated over $\sim 6 \mathrm{~m}$ over the year, but comparison of near-surface single-point sampling $(0.2 \mathrm{~m}$ depth) with velocity-weighted total suspended matter (TSM) measurements over a crosssection of the Oubangui indicated equivalent data for both dissolved and particulate material with the two approaches (1\% error, Coynel et al., 2005). All samples were shipped to the Katholieke Universiteit Leuven and the University of Liège for analyses approximately every 3 months.

Samples for dissolved gases $\left(\mathrm{CH}_{4}, \mathrm{~N}_{2} \mathrm{O}\right)$ and stable isotope composition of dissolved inorganic $\mathrm{C}\left(\delta^{13} \mathrm{C}_{\mathrm{DIC}}\right)$ were collected by a custom-made sampling bottle to avoid gas exchange, consisting of an inverted 11 polycarbonate bottle with the bottom removed, and $\sim 0.5 \mathrm{~m}$ of tubing attached in the screw cap. This sampler was held below the water surface to flush the bottle and tubing, after which it was inverted, and $12 \mathrm{ml}$ exetainer vials (for $\delta^{13} \mathrm{C}_{\mathrm{DIC}}$ ) and $50 \mathrm{ml}$ serum bottles (for $\mathrm{CH}_{4}$ and $\mathrm{N}_{2} \mathrm{O}$ ) were filled from water flowing from the outlet tubing, poisoned with $\mathrm{HgCl}_{2}$, and capped without headspace. Approximately 21 of water were collected $0.5 \mathrm{~m}$ 
below the water surface for other particulate and dissolved parameters, and filtration and sample preservation was performed within $2 \mathrm{~h}$ of sampling.

Samples for TSM were obtained by filtering $750 \mathrm{ml}$ of water on pre-combusted $\left(4 \mathrm{~h}\right.$ at $\left.500^{\circ} \mathrm{C}\right)$ and pre-weighed glass fiber filters $(47 \mathrm{~mm} \mathrm{GF} / \mathrm{F}, 0.7 \mu \mathrm{m}$ nominal pore size), and dried in ambient air. Samples for determination of particulate organic $\mathrm{C}(\mathrm{POC})$, particulate nitrogen $(\mathrm{PN})$ and $\mathrm{C}$ isotope composition of POC $\left(\delta^{13} \mathrm{C}_{\mathrm{POC}}\right)$ were collected from $200 \mathrm{ml}$ of water on pre-combusted $25 \mathrm{~mm}$ GF/F filters $(0.7 \mu \mathrm{m}$ nominal pore size). The filtrate from the TSM filtrations was further filtered on $0.2 \mu \mathrm{m}$ PES syringe filters (Sartorius, 16532Q) for total alkalinity (TA), and DOC and $\delta^{13} \mathrm{C}_{\mathrm{DOC}}(8-40 \mathrm{ml}$ glass vials with Polytetrafluoroethylene-coated septa). TA was analysed by automated electro-titration on $50 \mathrm{ml}$ samples with $0.1 \mathrm{moll}^{-1} \mathrm{HCl}$ as titrant (reproducibility estimated as typically better than $\pm 3 \mu \mathrm{mol} \mathrm{kg}{ }^{-1}$ based on replicate analyses). The partial pressure of $\mathrm{CO}_{2}\left(p \mathrm{CO}_{2}\right)$ and DIC concentrations were computed from $\mathrm{pH}$ and TA measurements using thermodynamic constants of Millero (1979) as implicated in $\mathrm{CO}_{2}$ SYS (Lewis and Wallace, 1998). Using an estimated error for $\mathrm{pH}$ measurements of $\pm 0.01 \mathrm{pH}$ units, $\pm 2 \mu \mathrm{M}$ for TA data, and $\pm 0.1{ }^{\circ} \mathrm{C}$ for temperature measurements, the propagated error is $\pm 1 \%$ for DIC, and $\pm 3 \%$ for $p \mathrm{CO}_{2}$.

We used two independent approaches to estimate the $\mathrm{CO}_{2}$ flux across the water-air interface based on measured $p \mathrm{CO}_{2}$ values. First, $\mathrm{CO}_{2}$ exchange was calculated as $F=$ $k \alpha \Delta p \mathrm{CO}_{2}$ where $k$ is the gas transfer velocity, $\alpha$ the solubility coefficient for $\mathrm{CO}_{2}$, and $\Delta p \mathrm{CO}_{2}$ represents the difference in partial pressure of $\mathrm{CO}_{2}$ between water and air. Atmospheric $p \mathrm{CO}_{2}$ from Mount Kenya (Kenya, $-0.05^{\circ} \mathrm{N}$ $37.80^{\circ} \mathrm{E}$ ) were retrieved GLOBALVIEW- $\mathrm{CO}_{2}$ data-base (Carbon Cycle Greenhouse Gases Group of the National Oceanic and Atmospheric Administration, Earth System Research Laboratory). Atmospheric $p \mathrm{CO}_{2}$ was converted from dry air to wet air using the water vapour algorithm given by Weiss and Price (1980).

$\mathrm{k}$-values were calculated based on the empirical relationships between wind speed and $k 600$ (i.e. $k$ normalized to a constant temperature of $20^{\circ} \mathrm{C}$ ) reported by Raymond and Cole (2001 - using equations for "all data" or "dome data"). Daily wind speed data were taken from the National Center for Environmental Prediction (NCEP) surface flux reanalysis dataset (http://www.cdc.noaa.gov/) for the nearest grid cell $\left(4.76^{\circ} \mathrm{N}, 18.75^{\circ} \mathrm{E}\right)$. This approach provides estimates of $\mathrm{k}$ that are based on a parameterisation using wind speed, and thus assumes that wind is the main generator of turbulence in rivers. Since turbulence in rivers is proportional to current speed (flow) and inversely proportional to depth (Alin et al., 2011; Butman and Raymond, 2011), we have also computed gas exchange fluxes using a gas transfer parameterization based on depth and water current that was developed for rivers and streams (O'Connor and Dobbins, 1958). This approach has been verified independently by field data in tidal rivers by Zappa et al. (2003) and Borges et al. (2004). Water current and river depth was recomputed from discharge data, based on relationships established from data reported by Olivry (1989). Average river depth ranged between 3.5 and $8.7 \mathrm{~m}$, and surface flow rates between 0.09 and $0.98 \mathrm{~m} \mathrm{~s}^{-1}$. The corresponding k-values ranged between 2.82 and 5.78 obviously increasing with river discharge.

For the analysis of $\delta^{13} \mathrm{C}_{\text {DIC }}$, a $2 \mathrm{ml}$ helium (He) headspace was created, and $\mathrm{H}_{3} \mathrm{PO}_{4}$ was added to convert all DIC species to $\mathrm{CO}_{2}$. After overnight equilibration, part of the headspace was injected into the He stream of an elemental analyser isotope ratio mass spectrometer (EA-IRMS, ThermoFinnigan Flash HT and ThermoFinnigan DeltaV Advantage) for $\delta^{13} \mathrm{C}$ measurements. The obtained $\delta^{13} \mathrm{C}$ data were corrected for the isotopic equilibration between gaseous and dissolved $\mathrm{CO}_{2}$ as described in Gillikin and Bouillon (2007), and measurements were calibrated with certified reference materials LSVEC and NBS-19. Concentrations of $\mathrm{CH}_{4}$ and $\mathrm{N}_{2} \mathrm{O}$ were determined via the headspace equilibration technique ( $20 \mathrm{ml} \mathrm{N} \mathrm{N}_{2}$ headspace in $50 \mathrm{ml}$ serum bottles) and measured by gas chromatography (GC, Weiss, 1981) with flame ionization detection (GC-FID) and electron capture detection (ECD-FID) with a SRI 8610C GC-FID-ECD calibrated with $\mathrm{CH}_{4}: \mathrm{CO}_{2}: \mathrm{N}_{2} \mathrm{O}: \mathrm{N}_{2}$ mixtures (Air Liquide Belgium) of 1,10 and $30 \mathrm{ppm} \mathrm{CH}_{4}$ and of $0.2,2.0$ and $6.0 \mathrm{ppm} \mathrm{N}_{2} \mathrm{O}$, and using the solubility coefficients of Yamamoto et al. (1976) for $\mathrm{CH}_{4}$ and Weiss and Price (1980) for $\mathrm{N}_{2} \mathrm{O}$.

$25 \mathrm{~mm}$ filters for POC, PN and $\delta^{13} \mathrm{C}_{\mathrm{POC}}$ were decarbonated with $\mathrm{HCl}$ fumes for $4 \mathrm{~h}$, re-dried and packed in $\mathrm{Ag}$ cups. POC, PN, and $\delta^{13} \mathrm{C}_{\mathrm{POC}}$ were determined on the abovementioned EA-IRMS using the thermal conductivity detector (TCD) signal of the EA to quantify POC and PN, and by monitoring $\mathrm{m} / \mathrm{z}, 44,45$, and 46 on the IRMS. An internally calibrated acetanilide and sucrose (IAEA-C6) were used to calibrate the $\delta^{13} \mathrm{C}_{\mathrm{POC}}$ data and quantify $\mathrm{POC}$ and $\mathrm{PN}$, after taking filter blanks into account. Reproducibility of $\delta^{13} \mathrm{C}_{\mathrm{POC}}$ measurements was better than $\pm 0.2 \%$. Subsamples from the $47 \mathrm{~mm} \mathrm{GF} / \mathrm{F}$ filters used for TSM were taken for analyses of the stable isotope composition of PN $\left(\delta^{15} \mathrm{~N}_{\mathrm{PN}}\right)$, packed in Ag cups (without prior acidification) and analysed using the abovementioned EA-IRMS with a $\mathrm{CO}_{2}$ scrubber inline, and using IAEA-N1 to calibrate resulting data. Samples for DOC and $\delta^{13} C_{\text {DOC }}$ were analysed as described in Bouillon et al. (2006). Typical reproducibility observed in duplicate samples was in most cases $< \pm 5 \%$ for DOC, and $\pm 0.2 \%$ for $\delta^{13} \mathrm{C}_{\text {DOC. }}$.

Lignin phenols were measured using the $\mathrm{CuO}$ oxidation method described by Hedges and Ertel (1982) with a number of modifications as described in Spencer et al. (2010b). Filtered waters (typically $250 \mathrm{ml}$ ) were acidified to $\mathrm{pH} 2$ with $12 \mathrm{~N} \mathrm{HCl}$ and subsequently rotary evaporated to $\sim 3 \mathrm{ml}$. The concentrate was then transferred to Monel reaction vessels (Prime Focus, Inc.) and dried under vacuum centrifugation. Samples were oxidized in a stoichiometric excess of $\mathrm{CuO}$, followed by acidification and ethyl acetate extraction procedures. After redissolution 
in pyridine, lignin phenols were silylated with N/O bistrimethylsilyltrifluoromethylacetamide. Quantification was carried out on a GC-MS (Agilent 6890 gas chromatograph equipped with an Agilent 5973 mass selective detector and a DB5-MS capillary column; $30 \mathrm{~m}, 0.25 \mathrm{~mm}$ inner diameter, Agilent) using cinnamic acid as an internal standard and a five-point calibration scheme. Eight lignin phenols were quantified for all samples, including three vanillyl phenols (vanillin, acetovanillone, vanillic acid), three syringyl phenols (syringaldehyde, acetosyringone, syringic acid), and two cinnamyl phenols (p-coumaric acid, ferulic acid). One blank was run for every ten samples and all samples were blank corrected. Blank concentrations of lignin phenols were low (30-40 ng) and consequently never exceeded $5 \%$ of the total lignin phenols in a sample.

Daily discharge $(Q)$ data at Bangui were provided by the Direction de la Météorologie Nationale. To calculate material fluxes integrated over the year of sampling, we compared different approaches. First, linear extrapolations were made between different sampling dates, daily fluxes were calculated as the product of the daily discharge and the measured or interpolated concentration, and summated over the entire sampling period. Given the number of sampling dates (28), the regular shape of the hydrograph, and the good correlation between discharge and concentrations, linear extrapolations are considered a suitable method (Tan et al., 2005). In addition, we used GUMLEAF v0.1 which uses a variety of algorithms with different complexity to calculate annual loads and to estimate their uncertainty. The full set of measured data are available as a Supplement.

\section{Results}

$Q$ during the study period ranged from 470 to $8540 \mathrm{~m}^{3} \mathrm{~s}^{-1}$, with a typical annual hydrograph showing a rising discharge from early May onward, peaking from mid September to mid November, followed by a gradual decrease towards low-flow conditions (Fig. 2). With a total annual discharge of $106 \mathrm{~km}^{3}$, equivalent to an average of $3361 \mathrm{~m}^{3} \mathrm{~s}^{-1}$, our study period is thus within the range observed over the past 4 decades (between 2000 and $4000 \mathrm{~m}^{3} \mathrm{~s}^{-1}$ ), but represents a relatively low discharge period when considering data since the early 20th century (Orange et al., 1997; Laraque et al., 2001). However, it is comparable to the average discharge during the period where most previous material flux data were collected (3005 $\mathrm{m}^{3} \mathrm{~s}^{-1}$; Coynel et al., 2005).

Water temperature varied between 26.8 and $31.5^{\circ} \mathrm{C}$, with lowest temperatures between mid July and the end of January (data in the Supplement). Conductivity ranged from 32.1 to $72.8 \mu \mathrm{S} \mathrm{cm}^{-1}$, decreasing non-linearly with increasing discharge and reaching stable values of $34.0 \pm 1.2 \mu \mathrm{S} \mathrm{cm}^{-1}$ at $Q>3000 \mathrm{~m}^{3} \mathrm{~s}^{-1}$ (Fig. 2). $\mathrm{pH}$ ranged from 6.67 to 8.24 , with higher values during low flow conditions, and lower values during high discharge (Fig. 2). $\% \mathrm{O}_{2}$ saturation ranged be-

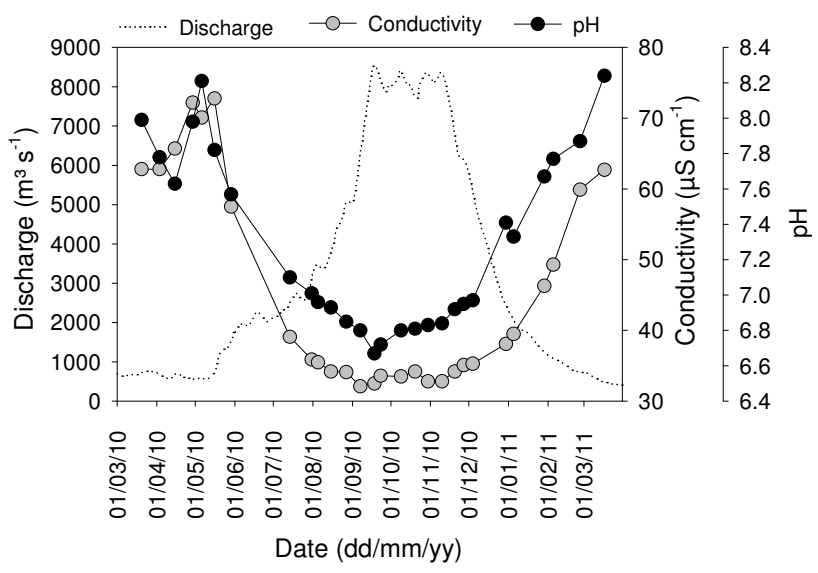

Fig. 2. Daily discharge data (dotted line) for the period March 2010-March 2011, and measured conductivity (grey symbols) and $\mathrm{pH}$ (black symbols) in the Oubangui River at Bangui.

tween 70.4 and $99.2 \%$, with only minor seasonality (data in the Supplement). TSM concentrations ranged from 2.0 to $33.2 \mathrm{mg}^{-1}$, increasing with discharge but with a clear hysteresis, i.e. lower concentrations at similar discharge during the falling limb of the hydrograph compared to the rising limb (Fig. 3a). POC concentrations ranged from $0.32 \mathrm{mg} \mathrm{Cl}^{-1}$ to $1.79 \mathrm{mgCl}^{-1}$ (Fig. 3), also with a clear hysteresis (Fig. 4) but with a much more limited range than observed in TSM ( $\sim 5$-fold for POC, $\sim 15$-fold for TSM). As a result, strong seasonal variations in the contribution of POC to the TSM pool (\%POC) occur, ranging from 4.8 to $25.7 \%$, with highest values occurring during low-flow conditions (Fig. 4). POC/PN ratios (mass-based) ranged from 4.7 to 11.9 , and were generally lower during low-flow conditions than during peak discharge (averages of $7.0 \pm 1.2$ when $Q<1200 \mathrm{~m}^{3} \mathrm{~s}^{-1}, n=11$, versus $10.9 \pm 0.6$ when $Q>6000 \mathrm{~m}^{3} \mathrm{~s}^{-1}, n=9$ ).

DOC concentrations ranged from 1.7 to $11.5 \mathrm{mg} \mathrm{Cl}^{-1}$, and showed a strong increase with discharge, increasing almost linearly during the rising limb of the hydrograph, and then dropping sharply during peak discharge, resulting in a clear hysteresis (Fig. 3c, see also Fig. 9). DOC dominated over POC throughout the hydrological year, contributing 67-97\% of the total organic C pool (83.3\% for the annual export, see further).

$\delta^{13} \mathrm{C}$ signatures of POC showed relatively strong seasonal variations, ranging from -30.6 to $-25.8 \%$ (Fig. 5). $\delta^{13} \mathrm{C}_{\mathrm{POC}}$ values were generally variable and more negative during low-flow conditions $(-28.6 \pm 1.3 \%$ when $\left.Q<1000 \mathrm{~m}^{3} \mathrm{~s}^{-1}, n=8\right)$ and gradually increased with discharge $\left(-26.1 \pm 0.3 \%\right.$ when $\left.Q>6000 \mathrm{~m}^{3} \mathrm{~s}^{-1}, n=9\right)$. Seasonal variations in $\delta^{13} \mathrm{C}_{\mathrm{DOC}}$ values (overall range between -31.8 and $-27.1 \%$ ) showed a markedly different and more complex pattern (Fig. 5), with stable values during the first part of the hydrograph $(-27.6 \pm 0.2 \%$ between March 

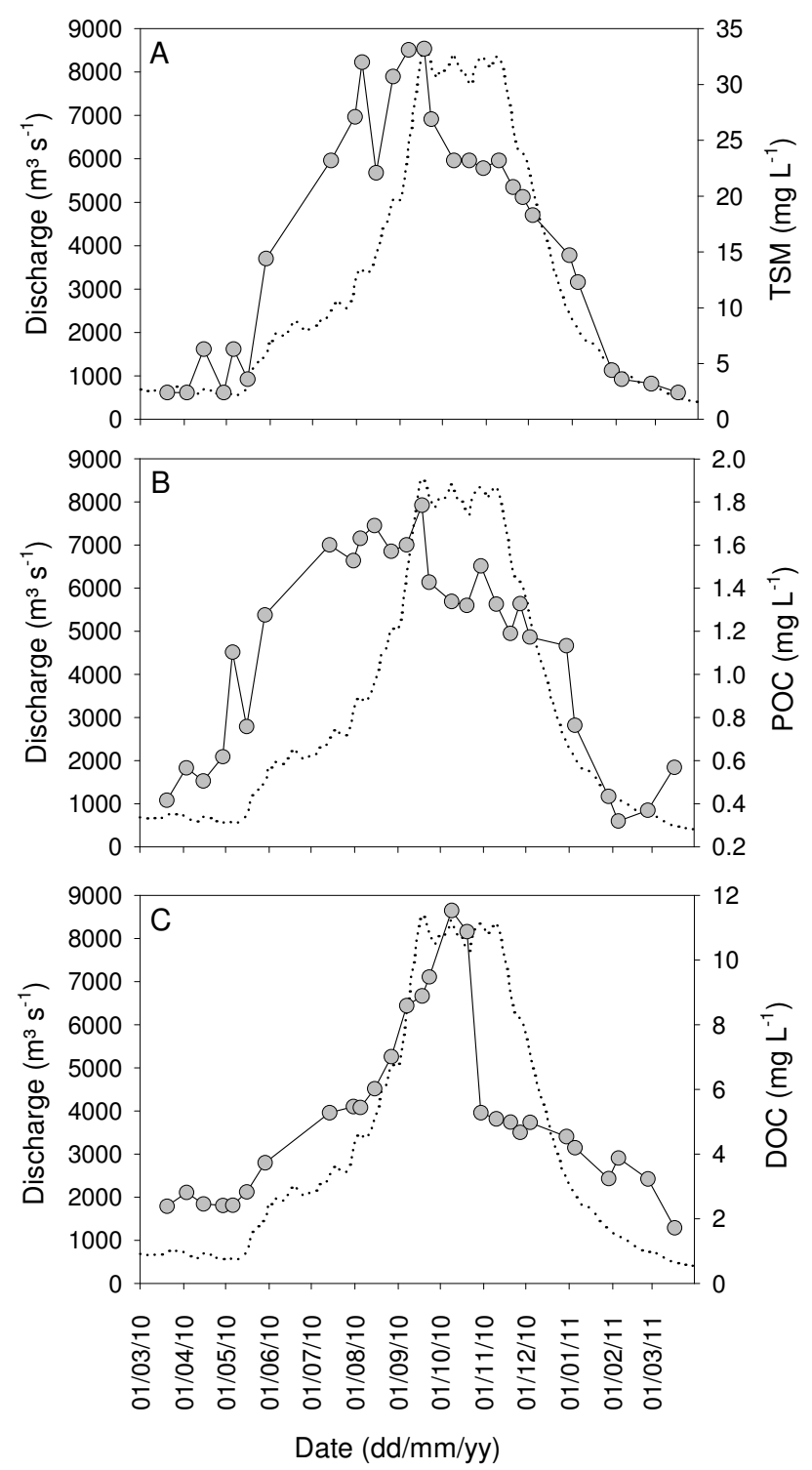

Fig. 3. Seasonal variations of daily discharge (dotted lines) and (A) total suspended matter (TSM), (B) particulate organic carbon, and (C) dissolved organic carbon, in the Oubangui River at Bangui between March 2010 and March 2011.

and early August), then gradually decreasing to low values (minimum of $-31.8 \%$ ) during peak discharge, and rising sharply to $\sim-29 \%$ o coinciding with the sharp drop in DOC concentrations observed after peak discharge is reached (Fig. 3 c). $\delta^{13} \mathrm{C}_{\mathrm{DOC}}$ values then decreased again to $\sim-31 \%$ o before returning to a low-discharge value of $\sim-27 \%$. Differences in $\delta^{13} \mathrm{C}$ signatures between POC and DOC pools $\left(\Delta \delta=\delta^{13} \mathrm{C}_{\mathrm{POC}}-\delta^{13} \mathrm{C}_{\mathrm{DOC}}\right)$ ranged from -2.3 to $+5.9 \%$ and were strongly correlated with discharge $\left(R^{2}=0.74\right.$, Fig. 6). $\delta^{15} \mathrm{~N}_{\mathrm{PN}}$ values varied from +2.7 to $+5.9 \%$ but showed no consistent seasonality (data in the Supplement).
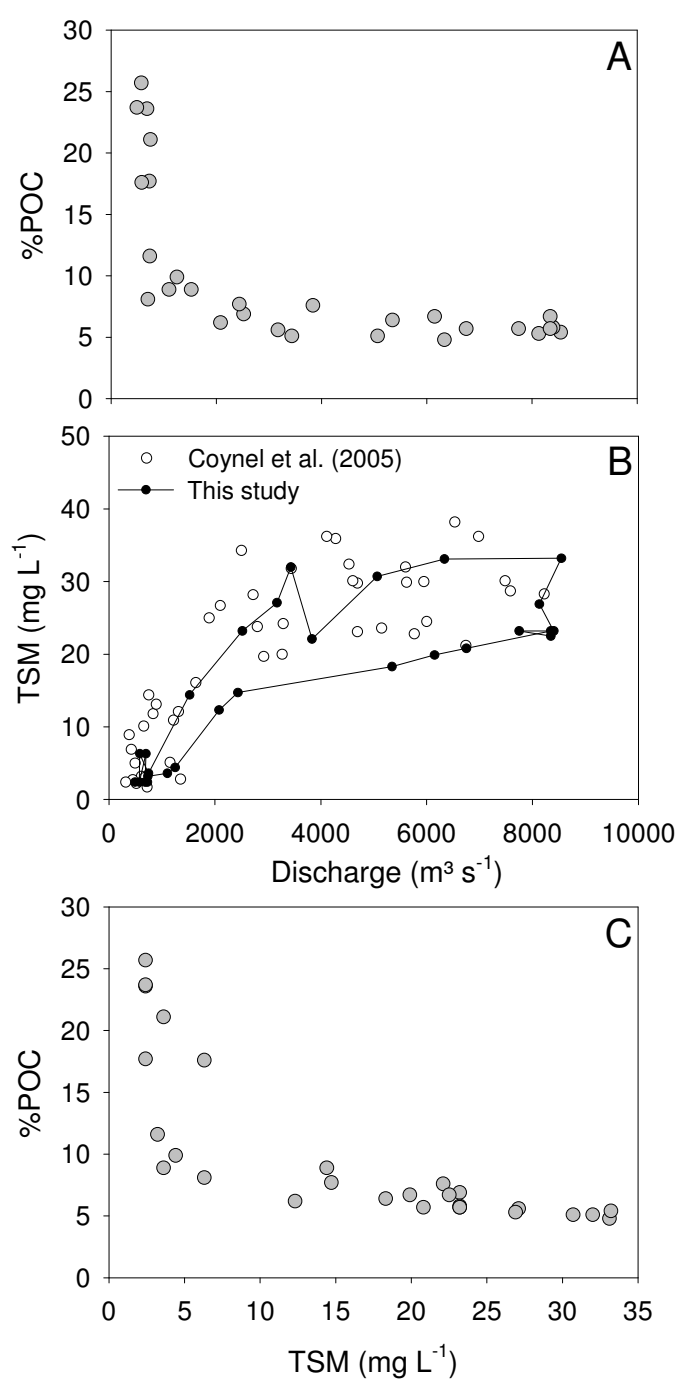

Fig. 4. Seasonal variations of (A) \%POC, and (B) TSM, showing hysteresis, with TSM data from this study compared with data from Coynel et al. (2005); and (C) relationship between TSM and \%POC.

TA varied between 0.234 and $0.600 \mathrm{mmol}^{-1}$, and showed a strong decrease during high discharge (Fig. 7a). DIC concentrations ranged from 0.314 to $0.615 \mathrm{mmoll}^{-1}$, following a similar annual cycle. DIC was the dominant $\mathrm{C}$ pool during low flow conditions ( $\sim 70 \%$ ), but contributed only $20-30 \%$ to the total $\mathrm{C}$ pool during high discharge (data not shown). The $p \mathrm{CO}_{2}$ showed a very strong seasonality, from values close to atmospheric equilibrium during low-flow conditions ( $470 \pm 203 \mathrm{ppm}$ for $Q<1000 \mathrm{~m}^{3} \mathrm{~s}^{-1}, n=10$ ) to a maximum of 3750 ppm during the first stage of peak discharge (Fig. 7a). $\mathrm{CO}_{2}$ undersaturation was observed on two of the sampling days (248 and $227 \mathrm{ppm}$ ). Given the relatively low variability in average daily wind speed $\left(1.26 \pm 0.61 \mathrm{~m} \mathrm{~s}^{-1}\right)$ and water temperature, estimated $\mathrm{CO}_{2}$ fluxes across the water-air atmosphere based on the parameterization of Raymond and Cole (2001) closely correlated with $p \mathrm{CO}_{2}$ values and ranged 


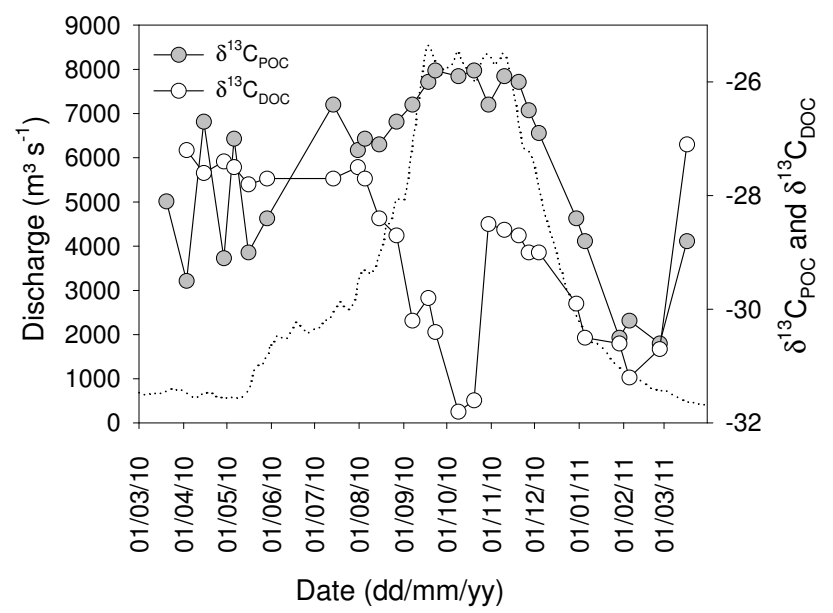

Fig. 5. Seasonal variations of daily discharge (dotted line) and $\delta^{13} \mathrm{C}$ signatures of particulate organic carbon (grey symbols) and dissolved organic carbon (open symbols), in the Oubangui River at Bangui between March 2010 and March 2011.

from -4.7 to $+73.9 \mathrm{mmol} \mathrm{CO}_{2} \mathrm{~m}^{-2} \mathrm{~d}^{-1}$, or from -4.6 to $+70.4 \mathrm{mmol} \mathrm{CO}_{2} \mathrm{~m}^{-2} \mathrm{~d}^{-1}$, using all or non-dome data, respectively. When extrapolated over the entire year, these estimates convert into an efflux of 107 and $105 \mathrm{~g} \mathrm{C} \mathrm{m}^{-2} \mathrm{yr}^{-1}$, respectively. Using water current and average depth to parameterize the gas exchange coefficient ( $\mathrm{O}^{\prime}$ Connor and Dobbins, 1958), estimated $\mathrm{CO}_{2}$ fluxes ranged between -3.1 and $+144.8 \mathrm{mmol} \mathrm{CO}_{2} \mathrm{~m}^{-2} \mathrm{~d}^{-1}$, resulting in an integrated flux of $204 \mathrm{~g} \mathrm{C} \mathrm{m}^{-2} \mathrm{yr}^{-1}$ (Table 2).

$\delta^{13} \mathrm{C}_{\mathrm{DIC}}$ values varied between -15.7 and $-8.6 \%$, with a decreasing trend with discharge: values were relatively high and stable during low flow conditions $(-9.3 \pm 0.5 \%$ o for $Q<1000 \mathrm{~m}^{3} \mathrm{~s}^{-1}, n=10$ ) but decreased strongly to values averaging $-14.3 \pm 0.8 \%$ o for $Q>6000 \mathrm{~m}^{3} \mathrm{~s}^{-1}$ (Fig. 7b).

Concentrations of dissolved $\mathrm{CH}_{4}$ (Fig. 8) varied between 74 and $280 \mathrm{nmol}^{-1}$, corresponding to high degrees of oversaturation (3450 to $13200 \%$ ). Highest $\mathrm{CH}_{4}$ concentrations were observed towards the end of the dry season, and decreased to stable values of $\sim 100 \mathrm{nmoll}^{-1}$ during high discharge. Concentrations of dissolved $\mathrm{N}_{2} \mathrm{O}$ (Fig. 8) varied between 6.2 and $9.6 \mathrm{nmoll}^{-1}$, corresponding to relatively minor degrees of oversaturation (112-165\%). $\mathrm{N}_{2} \mathrm{O}$ concentrations were lowest during low discharge conditions, with an initial rise during the onset of high flow and gradually decreasing concentrations after the peak discharge. Estimated $\mathrm{CH}_{4}$ fluxes across the water-air interface ranged from 38 to $248 \mu \mathrm{mol} \mathrm{m}{ }^{-2} \mathrm{~d}^{-1}$ using the Raymond and Cole (2001) parameterization for $k$, and from 71.3 to $350.4 \mu \mathrm{mol} \mathrm{m}^{-2} \mathrm{~d}^{-1}$ using the O'Connor and Dobbins (1958) parameterization with an extrapolated annual $\mathrm{CH}_{4}$ flux of 0.428 and $0.744 \mathrm{~g} \mathrm{C} \mathrm{m}^{-2} \mathrm{yr}^{-1}$, respectively. Estimated $\mathrm{N}_{2} \mathrm{O}$ fluxes varied between 0.596 and $2.184 \mu \mathrm{mol} \mathrm{N} \mathrm{m} \mathrm{N}^{-2} \mathrm{~d}^{-1}$ using the Raymond and Cole (2001) parameterization for $k$, and from

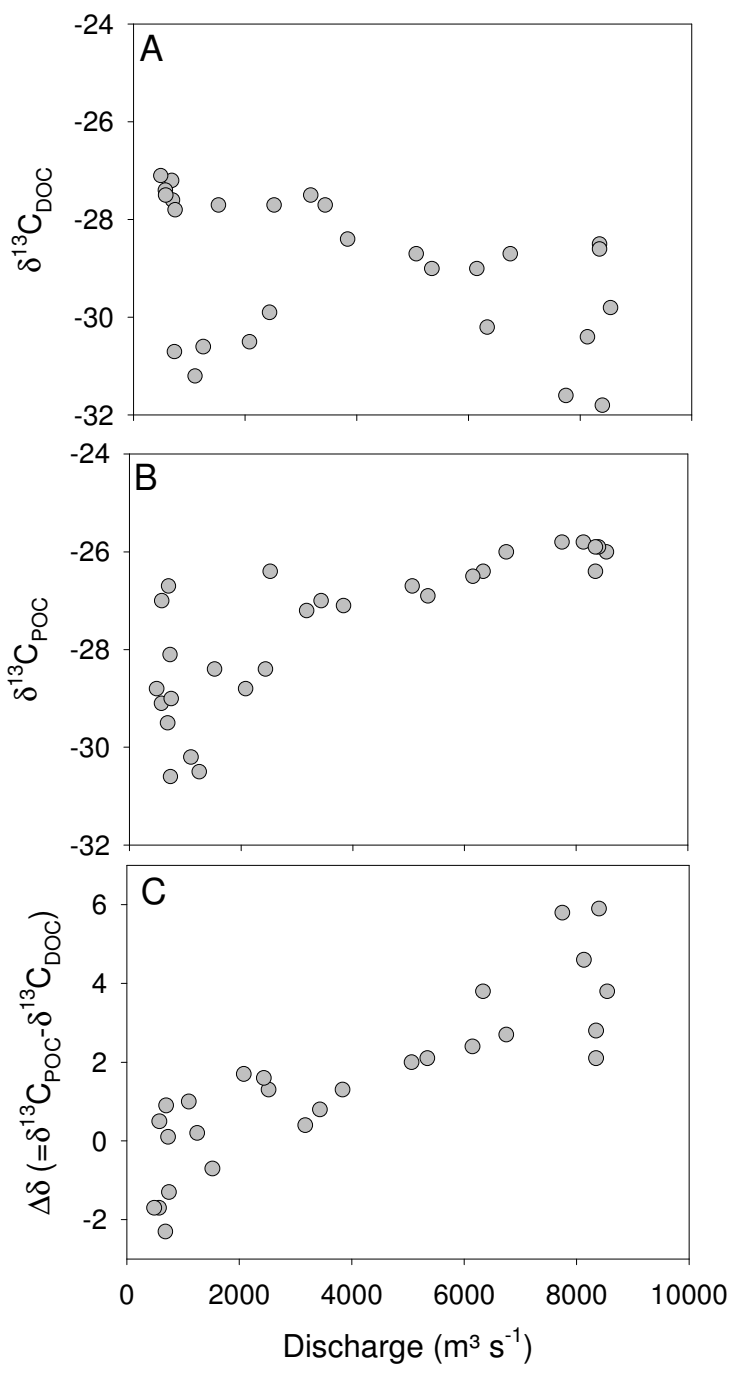

Fig. 6. Relationship between daily discharge and (A) $\delta^{13} \mathrm{C}$ signatures of DOC $(\mathbf{B}) \delta^{13} \mathrm{C}$ signatures of POC, and (C) $\Delta \delta$, i.e. the difference between $\delta^{13} \mathrm{C}$ signatures of POC and DOC, in the Oubangui River between March 2010 and March 2011.

0.674 to $5.690 \mu \mathrm{mol} \mathrm{m}^{-2} \mathrm{~d}^{-1}$ using the O'Connor and Dobbins (1958) parameterization, with an extrapolated annual $\mathrm{N}_{2} \mathrm{O}$ flux of $0.953 \mathrm{mmol} \mathrm{N}_{2} \mathrm{O} \mathrm{m} \mathrm{m}^{-2} \mathrm{yr}^{-1}$.

Carbon-normalized lignin yields $\left(\Lambda_{8}\right)$, defined as the sum of three vanillyl phenols, three syringyl phenols and two cinnamyl phenols normalized to DOC concentrations, ranged from 0.18 to $0.79 \mathrm{mg}(100 \mathrm{mg} \mathrm{OC})^{-1}$ and increased nonlinearly with DOC concentrations and discharge (Fig. 10a and Supplement). The ratios of vanillic acid to vanillin (hereafter as $(\mathrm{Ad}: \mathrm{Al})_{\mathrm{v}}$ ) and syringic acid to syringaldehyde (hereafter as $(\mathrm{Ad}: \mathrm{Al})_{\mathrm{s}}$ ) ranged between 1.00 and 2.20 $(1.47 \pm 0.42, n=24)$ and between 0.78 and $1.13(0.97 \pm 0.14$, $n=24)$, respectively. There was a relatively good correlation between both ratios $\left(R^{2}=0.73\right)$, and lower values were associated with high discharge and high DOC (e.g. 


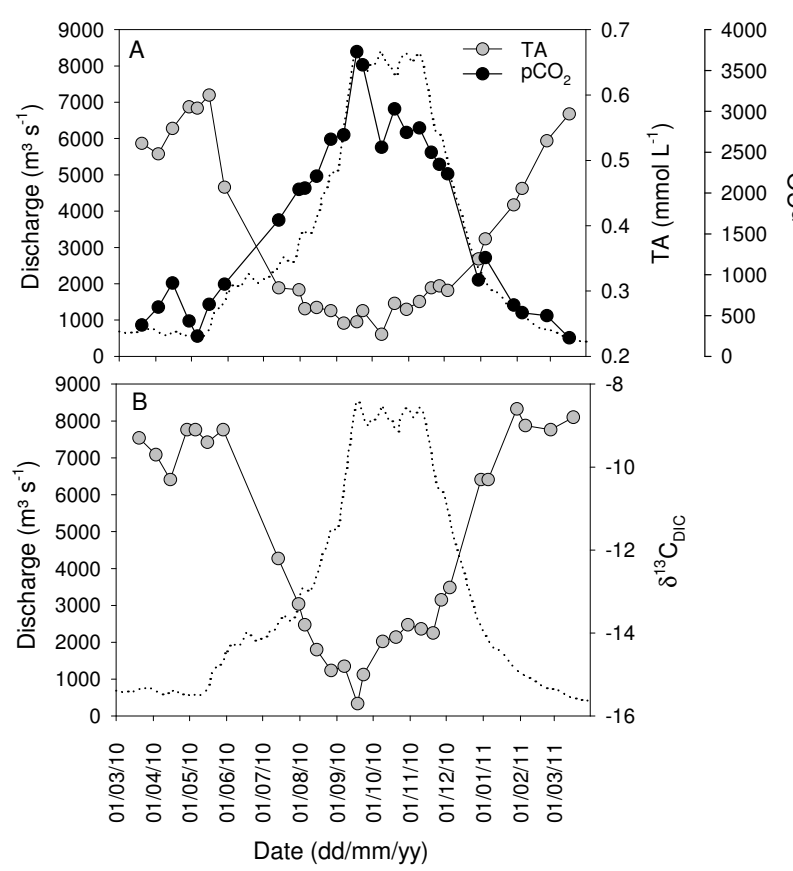

Fig. 7. Seasonal variations of daily discharge (dotted lines) and (A) total alkalinity (grey symbols) and $p \mathrm{CO}_{2}$ (black symbols), and (B) $\delta{ }^{13} \mathrm{C}$ signatures of dissolved inorganic carbon, in the Oubangui River at Bangui between March 2010 and March 2011.

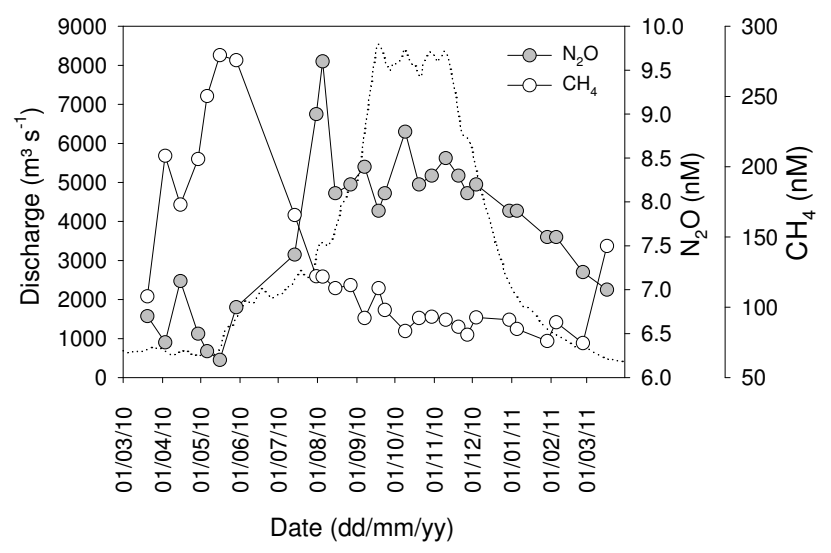

Fig. 8. Seasonal variations of daily discharge (dotted line) and concentrations of dissolved $\mathrm{CH}_{4}$ (open symbols) and $\mathrm{N}_{2} \mathrm{O}$ (grey symbols), in the Oubangui River at Bangui between March 2010 and March 2011.

Fig. 10b and Supplement). Cinnamyl:vanillyl (C:V) and syringyl:vanillyl phenol $(\mathrm{S}: \mathrm{V})$ ratios ranged between 0.15 and $0.56(0.24 \pm 0.09, n=24)$ and between 0.77 and 0.91 $(0.85 \pm 0.04, n=24)$, respectively. No consistent seasonal variations were observed in $\mathrm{S}: \mathrm{V}$ ratios. $\mathrm{C}: \mathrm{V}$ ratios $>0.25$ were only observed during low discharge $\left(Q<1000 \mathrm{~m}^{3} \mathrm{~s}^{-1}\right)$ and low DOC conditions, and were stable at $0.19 \pm 0.02$
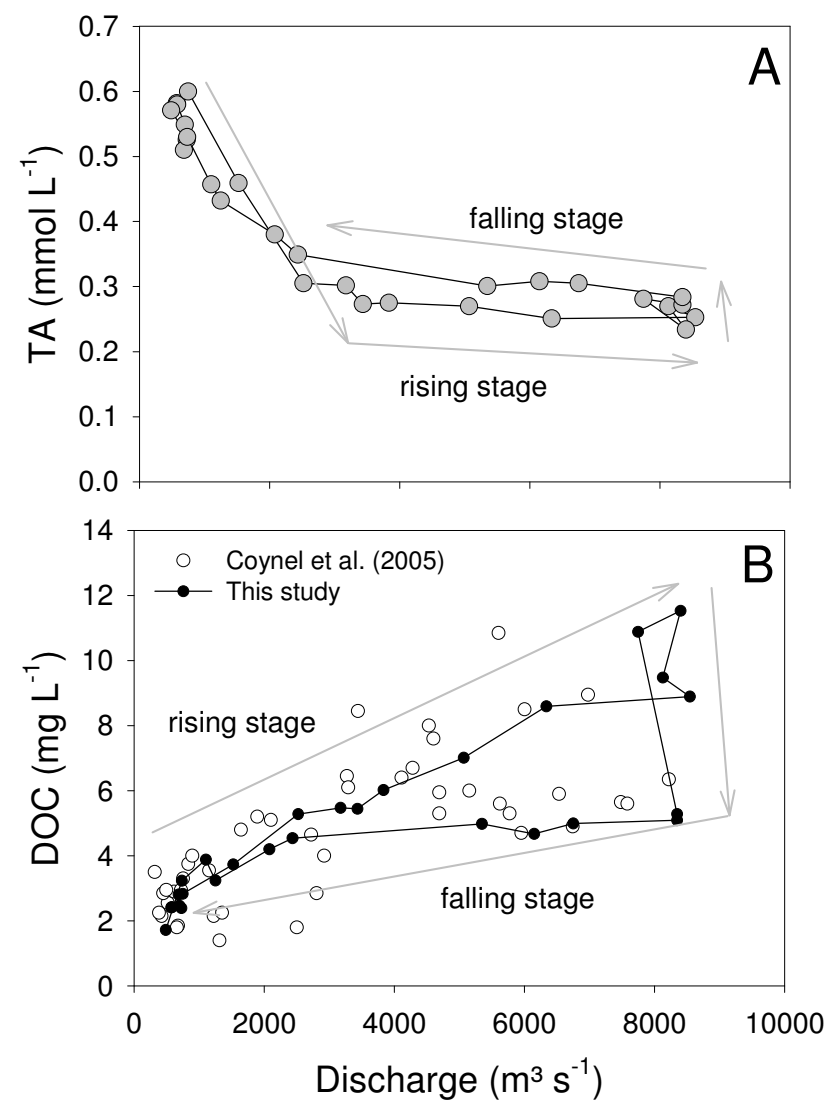

Fig. 9. Seasonal variations of (A) total alkalinity, and (B) dissolved organic carbon concentrations, showing different hysteresis patterns. DOC data from this study are compared with data from Coynel et al. (2005).

$(n=16)$ at higher discharge and DOC conditions (Fig. 10c and Supplement).

Material flux estimates are presented in Table 1. Estimates based on our linear extrapolation approach excellently matched with results obtained in GUMLEAF using seasonalstratified and flow regime-stratified Kendall's or Beale's ratio estimator, which are suggested to be most appropriate for datasets with daily discharge records and good sampling frequency across the hydrograph (see Tan et al., 2005), and which had low uncertainty estimates for our dataset (e.g. coefficients of variation between 5 and $9 \%$ for TSM load). Relative differences between our linear extrapolations and results from flow-regime stratified Beale's ratio estimators were $0.5-5.3 \%$ for TSM, POC, PN, DOC and DIC.

\section{Discussion}

This study reports initial results of a monitoring effort on the Oubangui River, where we measured a wide range of physico-chemical and biogeochemical proxies at approximately 2-weekly intervals. The discussion below follows the 
main objectives of our study: (i) quantify downstream fluxes of suspended matter and different $\mathrm{C}$ and $\mathrm{N}$ pools, (ii) characerise the sources of organic matter and inorganic $\mathrm{C}$ transported by the Oubangui River and their variations throughout the hydrograph, and (iii) constrain the water-atmosphere flux of important greenhouse gases $\left(\mathrm{CO}_{2}, \mathrm{CH}_{4}, \mathrm{~N}_{2} \mathrm{O}\right)$.

\subsection{Material fluxes}

When comparing our annual material transport fluxes with the available previous estimates (Table 1), there was an excellent correspondence with TSM and POC fluxes presented by Coynel et al. (2005), but our DOC flux $\left(0.702 \mathrm{Tg} \mathrm{yr}^{-1}\right)$ is $32 \%$ higher than previously estimated by Coynel et al. (2005), and our $\mathrm{HCO}_{3}^{-}$flux $\left(0.392 \mathrm{Tg} \mathrm{Cyr}^{-1}\right)$ is $35 \%$ lower than estimates presented by Probst et al. (1994). Interannual variations of fluxes for the Oubangui were considered minimal by Coynel et al. (2005), and given the similarity in total discharge during our sampling period and the average discharge during the period of earlier flux estimates (within $\sim 10 \%$ ), the $\pm 30 \%$ differences in flux estimates for DOC and $\mathrm{HCO}_{3}^{-}$are unlikely to be caused by hydrological differences alone. While the dataset used by Coynel et al. (2005) is somewhat more extensive since it is based on data collection over multiple years; our temporal sampling resolution is higher (28 sampling dates over the year, as compared to 12 or less in case of missing data, for previous studies). An overall plot of discharge-DOC concentrations shows general agreement in patterns between the Coynel et al. (2005) dataset and ours (Fig. 9b) indicating no apparent analytical bias in these concentration measurements. Hence, we assume that, apart from small variations in the annual discharge, an important driver for the differences observed in annual flux estimates for bicarbonate and DOC is the coarser temporal resolution used in flux calculations by Probst et al. (1994) and Coynel et al. (2005), as previous annual flux estimates were based on the mean annual water discharge and monthly discharge-weighted concentrations. According to our new estimates, the total $\mathrm{C}$ flux for the Oubangui during the period of study was $1.33 \mathrm{Tg} \mathrm{Cyr}^{-1}$, of which POC, DOC, and DIC comprise $10.6,52.9$ and $36.5 \%$, respectively. TSM, POC and DOC concentrations markedly increase with increasing discharge (Figs. 3, 4, 9) and hence, the majority of the transport fluxes occur during the wet season (e.g. $\geq 80 \%$ during 3 months with highest discharge). The contribution of DIC was a significant component of the total riverine $\mathrm{C}$ flux, although often neglected as a component of lateral transport of terrestrial C. Based on major element data and $\mathrm{Cl}^{-}$concentrations to correct for atmospheric inputs, Probst et al. (1994) estimated that $25 \%$ of the $\mathrm{HCO}_{3}^{-}$flux in the Oubangui is derived from carbonate dissolution, while the remainder is atmospheric, i.e. mainly derived from silicate weathering reactions consuming soil $\mathrm{CO}_{2}$. Considering the stoichiometry of carbonate dissolution, and assuming similar proportions for the DIC flux (rather than $\mathrm{HCO}_{3}^{-}$), this would imply that

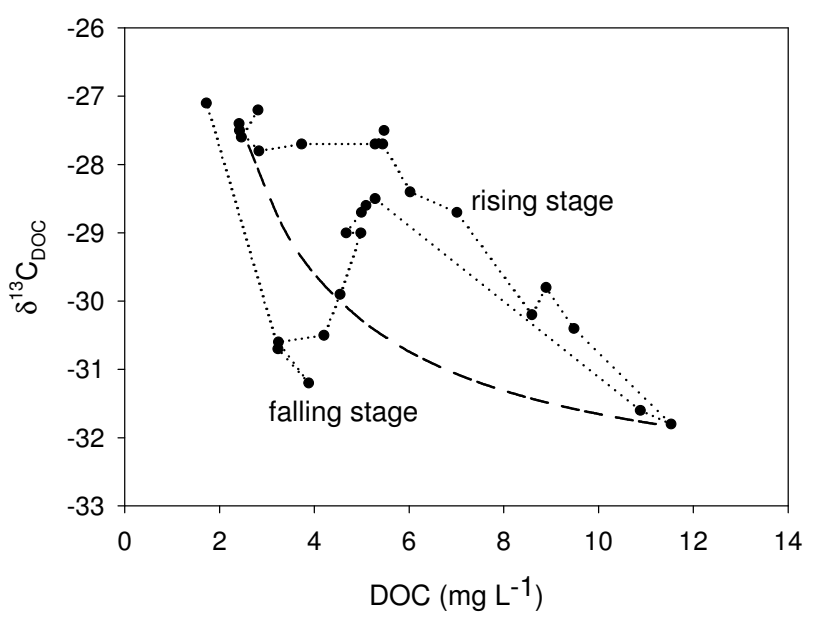

Fig. 10. Covariation between dissolved organic carbon concentrations the stable carbon isotope composition of DOC. Dotted lines connect data from subsequent sampling dates, curve represents a theoretical 2-source mixing scenario (see text for details).

$87.5 \%$ of the DIC flux is also ultimately derived from remineralisation of terrestrial organic matter in soils.

According to Probst et al. (1994), riverine transport of POC and DOC in the Congo River respresents $1.1 \%$ of the terrestrial net primary production (NPP) in the Congo Basin, and a similar value was proposed for the Amazon basin. More relevant, however, is a comparison with net ecosystem production (NEP). As a first-order estimate, if we assume a NEP rate of $0.23 \mathrm{Mg} \mathrm{C} \mathrm{ha}^{-1} \mathrm{yr}^{-1}$ for our study area (median value given for savannahs in Ciais et al., 2011) and extrapolate this over the catchment area $\left(489000 \mathrm{~km}^{2}\right)$, riverine export of TOC (DOC + POC) would represent $7.5 \%$ of the annual NEP, rising to $11.3 \%$ if we include transport of DIC and assume that $87.5 \%$ of the latter is ultimately derived from soil $\mathrm{CO}_{2}$ (see above). This estimate does not include outgassing of $\mathrm{CO}_{2}$ from the river and tributaries, as it would be inappropriate to extrapolate our $\mathrm{CO}_{2}$ flux estimates to the entire river network. These numbers should thus be considered preliminary, and model estimates on NEP from this region show a substantial degree of variability and uncertainty (e.g. Ciais et al., 2011 and CARBOSCOPE data, available on http://www.carboscope.eu/). Nevertheless, it suggests a relatively minor contribution of riverine $\mathrm{C}$ fluxes at the catchment scale, in line with recent data by Brunet et al. (2009) for the nearby Nyong River basin (Cameroon) where riverine transport of $\mathrm{C}$ and outgassing of $\mathrm{CO}_{2}$ was estimated to be equivalent to $\sim 3 \%$ of the net ecosystem $\mathrm{C}$ exchange in the basin.

Using a catchment area of $489000 \mathrm{~km}^{2}$, the estimated yields of TSM, POC and DOC for the Oubangui are 4.76, 0.29 and $1.43 \mathrm{t} \mathrm{km}^{-2} \mathrm{yr}^{-1}$, respectively. These yields are within the range of those found earlier in the Oubangui and the low yields for particulate material (TSM and POC) 
Table 1. Overview of particulate and dissolved fluxes calculated for the Oubangui (March 2010-March 2011), using both linear extrapolations between sampling dates, and using flow-regime stratified Beale's ratio estimators (FRS, GUMLEAF v0.1). Also provided are the annual weighted \%POC, annual weighted POC/PN ratio, and annual contribution of DOC to the total organic C export (\%DOC/TOC) based on both approaches. Literature data: from Probst et al. (1994) and Coynel et al. (2005), values in parenthesis are minimum and maximum values for different years from Coynel et al. (2005). \% Difference between literature data and this study is based on average values for linear and FRS extrapolations.

\begin{tabular}{|c|c|c|c|c|c|c|}
\hline & $\begin{array}{r}\text { LINEAR } \\
\mathrm{Tg} \mathrm{yr}^{-1}\end{array}$ & 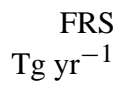 & $\mathrm{CV}(\%)$ & $\begin{array}{l}\% \text { Difference } \\
\text { (LIN vs. FRS) }\end{array}$ & $\begin{array}{r}\text { Literature } \\
\text { data }\end{array}$ & $\begin{array}{r}\% \text { Difference } \\
\text { (LIN vs. literature) }\end{array}$ \\
\hline TSM & 2.33 & 2.45 & 5 & 5.4 & $2.50(2.27-2.96)$ & -4.5 \\
\hline POC & 0.14 & 0.15 & 4 & 2.4 & $0.15(0.12-0.19)$ & -4.8 \\
\hline $\mathrm{PN}$ & 0.014 & 0.014 & 5 & -0.6 & & \\
\hline DOC & 0.70 & 0.73 & 7 & 3.3 & $0.54(0.43-0.65)$ & +32.1 \\
\hline DIC & 0.49 & 0.48 & 2 & -1.3 & & \\
\hline $\mathrm{C}-\mathrm{HCO}_{3}^{-}$ & 0.39 & 0.38 & & -3.5 & 0.59 & -34.5 \\
\hline$\% \mathrm{POC}^{3}$ & 6.1 & 5.9 & & & 6.0 & \\
\hline POC/PN (mass-based) & 9.9 & 10.2 & & & & \\
\hline$\% \mathrm{DOC}$ (of TOC) & 83.3 & 83.4 & & & 78.0 & \\
\hline
\end{tabular}

are characteristic of the Congo basin (Coynel et al., 2005; Laraque et al., 2009), likely due to the fact that much of the basin is characterized by low slopes. Overall particulate yields for the entire Congo Basin (8.2, and $0.6 \mathrm{t} \mathrm{km}^{-2} \mathrm{yr}^{-1}$ for TSM and POC according to Coynel et al., 2005) are indeed in the lower range of those found in river systems globally (see e.g. Stallard, 1998; Bird et al., 2008) and typical for transport-limited systems.

\subsection{Origin of POC and DOC}

For POC, there is a striking co-variation between \% POC and TSM concentrations (Fig. 4c), which has been noted earlier in both global studies (e.g. Meybeck, 1982) and within specific basins such as the Oubangui (Coynel et al., 2005). Two mechanisms have been invoked to explain such a relationship: (a) a higher contribution by in situ production (i.e. phytoplankton, with high \% POC) during periods of low turbidity, or (b) a gradient of contributions by direct litter inputs or topsoils (with higher \%POC) and deeper soil layers with lower \%POC during high runoff events. For the majority of rivers, the dominance of terrestrial material in the POC pool and the heterotrophic nature of the system likely implies that the latter hypothesis explains much of the observed variation. For the Oubangui, however, we propose that a high phytoplankton contribution during low flow conditions is the main cause of the covariation between \% POC and TSM. First, TSM concentrations are extremely low during low flow conditions $\left(<5 \mathrm{mg} \mathrm{l}^{-1}\right)$ and water residence times are high, which would favour the development of phytoplankton. Although chlorophyll data are not available due to logistical limitations, different proxies point towards a high phytoplankton contribution:

i. POC/PN ratios are low during low flow conditions $\left(7.0 \pm 1.2\right.$ when $Q<1200 \mathrm{~m}^{3} \mathrm{~s}^{-1}, n=11$, ver- sus $10.9 \pm 0.6$ when $\left.Q>6000 \mathrm{~m}^{3} \mathrm{~s}^{-1}, n=9\right)$. These low POC/PN ratios match with those expected when phytoplankton is predominant, and contrast with data from some of the rainforest-dominated tributaries of the Oubangui catchment and tributaries of the main Congo basin (Mariotti et al., 1991 and own unpublished data), where highest \% POC data typically coincide with high POC/PN ratios (12-20), indicative of direct litter inputs.

ii. A high phytoplankton contribution is consistent with the low $p \mathrm{CO}_{2}$ values recorded during low discharge conditions, including some values below atmospheric equilibrium suggesting the drawdown of $\mathrm{CO}_{2}$ by photosynthesis (Fig. 7a).

iii. $\delta^{13} \mathrm{C}_{\mathrm{POC}}$ values were generally variable during low-flow conditions $\left(-28.6 \pm 1.3 \%\right.$ when $Q<1000 \mathrm{~m}^{3} \mathrm{~s}^{-1}$, see Figs. 5 and 6) while showing a much smoother seasonal variation during the rest of the hydrograph. These shortterm variations in $\delta^{13} \mathrm{C}_{\mathrm{POC}}$ values, while not conclusive, would be consistent with varying contributions of phytoplankton and/or short-term changes in their $\delta^{13} \mathrm{C}$ signatures due to e.g. variations in growth rate or $\delta^{13} \mathrm{C}_{\mathrm{DIC}}$.

While phytoplankton is rarely considered as a significant carbon pool in large tropical rivers, Ellis et al. (2012) recently indicated that despite authochtonous, production can contribute to supporting heterotrophic communities in the Amazon River basin, even in relatively unproductive sites.

The $\delta^{13} \mathrm{C}_{\mathrm{POC}}$ values during high discharge conditions can be assumed to reflect the signature of topsoil and litterderived terrestrial organic C. As expected given the mixed savannah vegetation in much of the Oubangui catchment, the observed values $\left(-26.1 \pm 0.3 \%\right.$ when $Q>6000 \mathrm{~m}^{3} \mathrm{~s}^{-1}$, $n=9$ ) are somewhat more enriched compared to literature data on C3 vegetation $(-29.0 \pm 1.7 \%$ o for canopy vegetation; Cerling et al., 2004) and forest humus $(-27.4 \pm 0.5 \%$ 
, $n=7$; Schwartz, 1991) from the Congo basin, or the signature estimated for $\mathrm{C} 3$ vegetation $(-28.9 \%$ ) based on the empirical relationship of Kohn et al. (2010), based on precipitation and altitude. Using end-member values of between -29 and $-28 \%$ o for $\mathrm{C} 3$ vegetation, and $-12.4 \%$ o for C4 vegetation (based on Schwartz, 1991, and Cerling et al., 2004), the $\delta^{13} \mathrm{C}_{\mathrm{POC}}$ signatures would correspond to a $\mathrm{C} 4$ contribution of $12-18 \%$ during high discharge periods. The vegetation in the Oubangui catchment upstream of our sampling location consists of a semi-forested savannah mozaic (Runge and Nguimalet, 1995) with more densely forested areas often concentrated along the river network, and an increased aridity towards the northern sections of the catchment. The relatively low estimated $\mathrm{C} 4$ contribution could thus suggest that riparian zones contribute more to the riverine $\mathrm{C}$ pool than more distant landscape units (e.g. Dosskey and Bertch, 1994; Eckard et al., 2007).

Data on $\delta^{13} \mathrm{C}_{\mathrm{DOC}}$ for African river systems are scarce. Spencer et al. (2012) provides values of $-29.2 \%$ for the lower Congo River and $-27.9 \%$ for the Luilu River (southern savannah of the DR Congo), and Brunet et al. (2009) report a remarkably stable signature $(-29.0 \pm 0.04 \%$ ) for DOC samples collected at various locations over $2 \mathrm{yr}$ in the Nyong River basin (Cameroon) - both consistent with terrestrial C3 vegetation as the predominant source of DOC in these systems. In the Tana River basin (Kenya), which contains significant areas of C4 vegetation, Bouillon et al. (2009) found dry season $\delta^{13} \mathrm{C}_{\mathrm{DOC}}$ signatures to be relatively stable throughout the catchment, averaging $-23.9 \pm 0.3 \%$ o. The relatively strong seasonal variation in $\delta^{13} \mathrm{C}_{\mathrm{DOC}}$ values observed in this study is thus surprising and suggest that DOC sources vary considerably during the hydrological year. The evolution of DOC concentrations follows a clear hysteresis loop, with lower DOC concentrations during the falling stages of the hydrograph, as previously noted by Coynel et al. (2005) for the Oubangui. The occurrence of hysteresis loops for DOC and other solutes in general has sometimes been interpreted as a "flushing" effect, whereby baseflow values are considered reflective of a predominant groundwater signature, and changes in concentrations are the result of event water flushing DOC from soils (Boyer et al., 1996). Such a two-component mixing model is however insufficient to explain many types of hysteresis loops observed, and a more elaborate framework consistent with observations assumes that a discharge peak is composed of three components, i.e. baseflow (i.e. groundwater), soil water and surface event water, with their relative contributions varying over the hydrograph. Different solute concentrations in each of these end-members then result in hysteresis loops in different shapes (Evans and Davies, 1998), although care should be taken in their interpretation as different combinations can result in similar loop types (Chanat et al., 2002). Interestingly, two recent studies show DOC and $\delta^{13} \mathrm{C}_{\mathrm{DOC}}$ variations in streamwater across the hydrograph that are very similar to our observations despite the fact that the systems stud- ied comprised much smaller catchments. Both Sanderman et al. (2009) and Lambert et al. (2011) observed an increase in DOC during the rising limb is accompanied by a strong decrease in $\delta^{13} \mathrm{C}_{\mathrm{DOC}}$ signatures by $2-5 \%$. These two studies provide $\delta^{13} \mathrm{C}_{\mathrm{DOC}}$ data of soil profiles in their respective catchments, which show a marked increase in $\delta^{13} \mathrm{C}_{\mathrm{DOC}}$ with increasing depth, and interpret these variations as the combined effect of differences in water routing during the hydrograph and differences in the DOC characteristics along the soil profile.

The pattern of covariation in DOC and $\delta^{13} \mathrm{C}_{\mathrm{DOC}}$ values for the Oubangui (Fig. 11) confirms that a two-component mixing model is insufficient to describe their seasonal variations. During the rising stage of the hydrograph there is a consistent increase in DOC and decrease in $\delta^{13} \mathrm{C}_{\mathrm{DOC}}$, a sharp backfall to lower DOC and higher $\delta^{13} \mathrm{C}_{\mathrm{DOC}}$ in the centre of the high flow period, but after this $\delta^{13} \mathrm{C}_{\mathrm{DOC}}$ values again strongly decrease despite a further decrease in DOC concentrations. This complex pattern deviates substantially from a two-component mixing model based on low- and high water DOC concentrations and their corresponding $\delta^{13} \mathrm{C}_{\mathrm{DOC}}$ signatures (for end-member values, see description below; curve on Fig. 11). However, even a conservative 3-source model with constant DOC concentrations and $\delta^{13} \mathrm{C}$ signatures in the end-members would be insufficient to explain the variations observed in Fig. 11. This indicates that either one of the endmember source waters has a DOC or $\delta^{13} \mathrm{C}$ signature which is variable over time (e.g. decreasing concentrations after the DOC built up during dry periods is exhausted, as proposed by Boyer et al., 1996), and/or that there is significant regulation of either DOC concentrations or $\delta^{13} \mathrm{C}$ signatures during transport. Riparian zones, for example, have been shown to exert strong control over DOC transport into river channels due to sorption/desorption reactions (Remington et al., 2007), and catchment-scale models have also suggested that DOC delivery to streams cannot always be explained by a simple hydrological routing (Stutter et al., 2012).

The $\delta^{13} \mathrm{C}$-DOC data measured in particular during the early part of the high discharge period are surprisingly low (down to $-31.8 \%$ ). During this stage of the hydrograph, we expect the majority of DOC to be derived from surface soil horizons, but riverine $\delta^{13} \mathrm{C}_{\mathrm{DOC}}$ are lower than the expected $\delta^{13} \mathrm{C}$ of terrestrial C3 vegetation $(-28.9 \%$ based on Kohn (2010), see higher). One possible explanation would be that the Kohn (2010) model overestimates vegetation $\delta^{13} \mathrm{C}$ signatures, e.g. due to closed canopy effects and generally higher water availability in the riparian zone which would lead to lower $\delta^{13} \mathrm{C}$ signatures. On the other hand, the fact that DOC is substantially more depleted in ${ }^{13} \mathrm{C}$ than $\mathrm{POC}$ during this period (see Fig. 6) would imply that their main origin is spatially segregated, i.e. DOC signatures are influenced more by the riparian vegetation (see Remington et al., 2007) than POC which would be of a more distant origin. Further insights into the dynamics of DOC can be gleaned from the dissolved lignin signatures (Fig. 10). 
Different lignin signatures show strong contrasts between low-discharge and high-discharge conditions: (i) $\Lambda_{8}$ are markedly lower during low-discharge conditions $\left(0.25 \pm 0.05, n=9\right.$ for $\left.Q<1000 \mathrm{~m}^{3} \mathrm{~s}^{-1}\right)$ which corresponds to DOC concentrations $<4 \mathrm{mgl}^{-1}$ ) compared to highdischarge conditions $(0.64 \pm 0.11, n=16)$ corresponding to higher DOC concentrations, (ii) $(\mathrm{Ad}: \mathrm{Al})_{\mathrm{v}}$ ratios are considerably higher during low-flow conditions $(2.01 \pm 0.18$, $n=9$ versus $1.20 \pm 0.13, n=16$ ), and (iii) high $\mathrm{C}: \mathrm{V}$ ratios $(0.33 \pm 0.11, n=9)$ were observed during low discharge $\left(Q<1000 \mathrm{~m}^{3} \mathrm{~s}^{-1}\right)$ and low DOC conditions, and were stable at $0.19 \pm 0.02(n=16)$ at higher discharge and DOC conditions.

Using both low-DOC and high-DOC end member signatures, two-end member mixing curves can be plotted to describe the theoretical pattern expected, if variations in lignin signatures were primarily caused by differential contributions of two water masses (e.g. baseflow and event flow) with different DOC concentrations and lignin characteristics. To construct a simple 2-source mixing model, we used the following end-members characteristics: (i) DOC: $2.48 \mathrm{mg} \mathrm{l}^{-1}$, Al: $0.804 \mu \mathrm{g} \mathrm{l}^{-1}$, Ad: $1.610 \mu \mathrm{g} 1^{-1}$ (hence Ad:Al: 2.00), S8: $6.11 \mu \mathrm{g} 1^{-1}$, and $\delta^{13} \mathrm{C}_{\mathrm{DOC}}$ : $-27.5 \%$ for the low DOC endmember, and (ii) DOC: $11.21 \mathrm{mgl}^{-1}$, Al: $11.624 \mu \mathrm{gl} \mathrm{l}^{-1}$, Ad: $12.792 \mu \mathrm{g} 1^{-1}$ (hence Ad:Al: 1.12), S8: $65.60 \mu \mathrm{gl} 1^{-1}$, and $\delta^{13} \mathrm{C}_{\mathrm{DOC}}:-31.8 \%$ for the high DOC end-member. Based on these end-member signatures, the concentrations, lignin characteristics and $\delta^{13} \mathrm{C}_{\mathrm{DOC}}$ can be predicted for each combination of contributions from both sources. As observed in Fig. 10, while the $(\mathrm{Ad}: \mathrm{Al})_{\mathrm{v}}$ variations are not inconsistent with such a mixing curve, the much higher than expected $\Lambda_{8}$ values at intermediate DOC concentrations confirm the above conclusion based on DOC and $\delta^{13} \mathrm{C}_{\mathrm{DOC}}$ data that at least three different sources are required to explain the seasonal variations in dissolved organic matter and its characteristics.

When comparing the lignin signatures with data from other sites in the Congo River basin, a number of interesting patterns emerge (Fig. 10). First, the strong seasonal variations observed in Oubangui lignin compositions contrast with data from the rainforest-dominated Epulu River catchment where seasonal variations in $\mathrm{C}: \mathrm{V}$ and $(\mathrm{Ad}: \mathrm{Al})_{\mathrm{v}}$ were minor (Spencer et al., 2010a). Whereas the lignin compositions in the Epulu River, where the catchment is dominated by rainforest vegetation, were indicative of a single source such as a shallow litter/organic soil layer, the compositions in the Oubangui are consistent with deeper and more welldeveloped soils containing significant gradients in soil organic matter concentration and composition - consistent with other proxies (see above) pointing towards clear differences in the origin of both dissolved and particulate organic matter fractions. Second, the lignin signatures observed during high discharge conditions fit well with those observed in the lower Congo River (Spencer et al., 2012) (Fig. 10). However, signatures during low flow conditions (and low DOC

Fig. 11. Covariation between dissolved organic carbon concentrations and $(\mathbf{A})$ carbon-normalized lignin yields $\left(\Lambda_{8}\right),(\mathbf{B})(\mathrm{Ad}: \mathrm{Al})_{\mathrm{V}}$ ratios, and (C) $\mathrm{C}: \mathrm{V}$ ratios, for the Oubangui River at Bangui between March 2010 and March 2011 (grey symbols), along with literature data from other locations in the Congo River basin (open and black symbols, see legend). Lines on (A) and (B) show a theoretical two end-member mixing scenario (see text for details). 
Table 2. Summary of published $p \mathrm{CO}_{2}$ and $\mathrm{CO}_{2}$ flux data from river systems on the African continent, and comparison with median values reported for tropical rivers and streams. Anomalously high values for the Niger River from Camail et al. (1987) are excluded as these are considered erroneous (see Cole and Caraco, 2001), and data from Mengong Spring also not included (Brunet et al., 2009). Range of CO 2 fluxes given for the Nyong River basin are annual averages for different sites (see Brunet et al., 2009). $p \mathrm{CO}_{2}$ and $\mathrm{CO}_{2}$ fluxes in Ivory Coast (Koné et al., 2009) are annual averages based on 4 seasonal surveys of 8 stations per river.

\begin{tabular}{llll}
\hline Site & $p \mathrm{CO}_{2}$ & $\mathrm{CO}_{2}$ flux $\left(\mathrm{g} \mathrm{C} \mathrm{m}^{-2} \mathrm{yr}^{-1}\right)$ & Reference \\
\hline Niger River, Lokoja, Niger & $2470 \pm 1340(n=13)$ & n.d. & Martins (1982) \\
Nile River, Giza, Egypt (1959) & $2110 \pm 540(n=13)$ & n.d. & Kempe (1983) \\
Nile River, Giza, Egypt (1969) & $1365 \pm 630(n=13)$ & n.d. & Kempe (1983) \\
Gambia River, Gambia & $2072 \pm 669(n=12)$ & n.d. & Lesack et al. (1984) \\
Tana River basin, Kenya & range: $110-3570(n=25)$ & n.d. & Bouillon et al. (2009) \\
Nyong River basin, Cameroon & $7245 \pm 3046(n=185)$ & $1000-2600$ & Brunet et al. (2009) \\
Bia River, Ivory Coast & $2418 \pm 269(n=32)$ & $215 \pm 105$ & Koné et al. (2009) \\
Tanoé River, Ivory Coast & $5602 \pm 2806(n=32)$ & $600 \pm 425$ & Koné et al. (2009) \\
Comoé River, Ivory Coast & $4334 \pm 1770(n=32)$ & $745 \pm 495$ & Koné et al. (2009) \\
Oubangui River, Bangui (CAR) & $1678 \pm 1092(n=28)$ & $105-204$ (annual basis) & This study, different approaches \\
Median estimated for tropical & $3600-4300$ & $1600-2720$ & Aufdenkampe et al. (2011) \\
rivers and streams, respectively & & & \\
\hline
\end{tabular}

concentrations) are clearly distinct from other sites studied so far in the Congo Basin and can thus be proposed to represent baseflow signatures from a mixed savannah-dominated region. The high $\mathrm{C}: \mathrm{V}$ ratios observed during low flow would suggest increased inputs from savannah sources, e.g. grasses in the Amazon have been shown to have a high $\mathrm{C}: \mathrm{V}$ near 1.0 (Hedges et al., 1986). Similarly, Spencer et al. (2012) observed higher $\mathrm{C}: \mathrm{V}$ ratios in the savannah-draining Luilu River compared to the mainstem Congo River.

\subsection{Greenhouse gas fluxes and sources}

The necessity to including riverine gas exchange in regional carbon budgets has been addressed in a number of studies (e.g. Richey et al., 2002; Butman and Raymond, 2011), and the most recent estimates suggest that outgassing is disproportionately higher in the tropical zone (Aufdenkampe et al., 2011). However, the empirical database on which these statements are made is strongly biased towards river systems in South America and Southeast Asia, with only a handful of studies reporting $p \mathrm{CO}_{2}$ data or $\mathrm{CO}_{2}$ flux estimates from African river systems (compiled in Table 2). Using two different approaches to parameterize gas exchange coefficient (see Materials and methods), our annually integrated water-air $\mathrm{CO}_{2}$ exchange values range between 105 and $204 \mathrm{~g} \mathrm{C} \mathrm{m}^{-2} \mathrm{yr}^{-1}$ using either the Raymond and Cole (2001) or O'Connor and Dobbins (1958) parameterization, respectively (Table 2). Our $p \mathrm{CO}_{2}$ data and estimated annual $\mathrm{CO}_{2}$ fluxes for the Oubangui indicate two important considerations:

i. First, the $p \mathrm{CO}_{2}$ data are surprisingly low compared to global "median" $p \mathrm{CO}_{2}$ values estimated for large tropical river systems $(3600 \mathrm{ppm}$ for rivers $>100 \mathrm{~m}$, Aufdenkampe et al., 2011), and this appears to hold true for data from the few other African river systems with the exception of the Nyong river basin data (see Table 2). These lower $p \mathrm{CO}_{2}$ data will translate into lower $\mathrm{CO}_{2}$ fluxes across the water-air interface, although most studies have not provided direct or indirect estimates of $\mathrm{CO}_{2}$ evasion (Table 2). Clearly, a data from a wider range of tropical rivers with sufficient ancillary data would be useful to examine whether driving factors can be determined which explain the high variability observed in $\mathrm{CO}_{2}$ evasion from these systems.

ii. Secondly, the $p \mathrm{CO}_{2}$ and $\mathrm{CO}_{2}$ flux data show a very pronounced seasonal pattern which is strongly linked to the hydrological conditions: $p \mathrm{CO}_{2}$ values were close to atmospheric equilibrium during low-flow conditions, reaching a maximum of $3750 \mathrm{ppm}$ during the first stage of peak discharge (Fig. 7a), a seasonality also reflected in estimated $\mathrm{CO}_{2}$ fluxes across the water-air interface. This strong seasonality highlights the critical importance of sampling over different hydrological conditions to properly average and upscale $\mathrm{CO}_{2}$ fluxes (see also Richey et al., 2002). Moreover, the low and occasionally below atmospheric equilibrium $p \mathrm{CO}_{2}$ values demonstrate that during low-flow conditions, aquatic primary production can be substantial in this large tropical river and exert a strong influence on the $\mathrm{CO}_{2}$ balance.

The seasonal pattern in $p \mathrm{CO}_{2}$ mirrors that observed in stable carbon isotope signatures of DIC (Fig. 7b), resulting in a strong negative correlation between both variables (Fig. 12). $\delta^{13} \mathrm{C}_{\text {DIC }}$ values in surface waters are influenced by a range of processes, including the relative contribution of silicate versus carbonate weathering, photosynthesis and mineralisation, and $\mathrm{CO}_{2}$ outgassing. Silicate weathering produces DIC with a signature similar to that of soil $\mathrm{CO}_{2}$ (i.e. $\mathrm{CO}_{2}$ derived from 


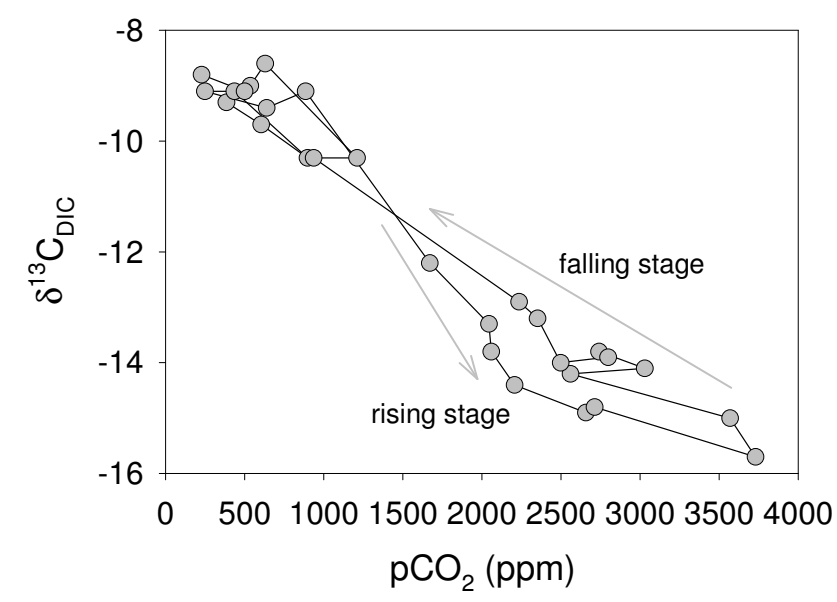

Fig. 12. Covariation between $p \mathrm{CO}_{2}$ values and the carbon stable isotope composition of dissolved inorganic carbon, for the Oubangui River at Bangui between March 2010 and March 2011.

mineralisation of soil organic matter; Bullen and Kendall, 1998). The latter should be expected to be $\sim-26 \%$ o based on the $\delta^{13} \mathrm{C}$ values observed for POC during high discharge which are expected to reflect predominantly soil runoff. Carbonate weathering, in contrast, results in higher $\delta^{13} \mathrm{C}_{\mathrm{DIC}}$ values since half of the bicarbonate formed originates from soil $\mathrm{CO}_{2}$, while the other half originates from carbonates, which we assume here to have a signature of around $0 \%$. Photosynthesis and respiration have opposite effects on $\delta^{13} \mathrm{C}_{\mathrm{DIC}}$ values as photosynthesis is associated with fractionation, leaving the residual DIC pool enriched in ${ }^{13} \mathrm{C}$, while mineralisation adds DIC with a ${ }^{13} \mathrm{C}$-depleted signature similar to that of the organic matter being mineralised. Finally, $\mathrm{CO}_{2}$ evasion leads to a gradual ${ }^{13} \mathrm{C}$-enrichment of the DIC pool, since dissolved $\mathrm{CO}_{2}$ is strongly ${ }^{13} \mathrm{C}$-depleted relative to bicarbonate (see Doctor et al., 2008).

Substantial seasonality in $\delta^{13} \mathrm{C}_{\mathrm{DIC}}$ is observed in many river sytems (e.g. Hellings et al., 2001; Brunet et al., 2009), and the range found in our study $(7.1 \%$ ) shows evidence for the contribution of these different processes in driving the DIC dynamics. $\delta^{13} \mathrm{C}_{\text {DIC values show a strong non-linear }}$ correlation with $\mathrm{Ca}^{2+} / \mathrm{Si}$ ratios (data not shown), with more negative $\delta^{13} \mathrm{C}_{\text {DIC }}$ values associated with low $\mathrm{Ca}^{2+} / \mathrm{Si}$ ratios. This pattern is consistent with the overall effect of differences in carbonate vs. silicate weathering on $\delta^{13} \mathrm{C}_{\mathrm{DIC}}$ values. On the other hand, if we assume a carbonate $\delta^{13} \mathrm{C}$ signature of $0 \%$ and a soil $\mathrm{CO}_{2} \delta^{13} \mathrm{C}$ between -24 and $-28 \%$, even the lowest $\delta^{13} \mathrm{C}_{\mathrm{DIC}}$ signatures are 5-9\%o less negative than what would be expected based on the estimate of Probst et al. (1994) that $75 \%$ of the bicarbonate flux in the Oubangui is derived from silicate weathering. Assuming the latter data are correct, such a discrepancy in $\delta^{13} \mathrm{C}_{\text {DIC }}$ would suggest that significant outgassing of $\mathrm{CO}_{2}$ occurs higher up in the catchment (in soils and/or in lower order rivers), which is not unlikely given the size of the Oubangui catchment. Fi- nally, the higher $\delta^{13} \mathrm{C}_{\text {DIC }}$ values during low discharge conditions would also be consistent with the idea of significant in situ phytoplankton production as outlined above.

Riverine $\mathrm{CH}_{4}$ dynamics are virtually unstudied for any African catchment. $\mathrm{CH}_{4}$ concentrations were within the range of those reported for the Tana River basin (Bouillon et al., 2009), and for the Comoé, Bia and Tanoé rivers in Ivory Coast (Koné et al., 2010). The annually extrapolated diffusive $\mathrm{CH}_{4}$ efflux for the Oubangui $\left(0.428 \mathrm{~g} \mathrm{C} \mathrm{m}^{-2} \mathrm{yr}^{-1}\right)$ is somewhat lower than estimates for the abovementioned Ivory Coast rivers $\left(0.662-1.230 \mathrm{~g} \mathrm{C} \mathrm{m}^{-2} \mathrm{yr}^{-1}\right.$, Koné et al., 2010), and at the low end of the range compiled by Bastviken et al. (2011) for temperate rivers $\left(0.04-43.8 \mathrm{~g} \mathrm{C} \mathrm{m}^{-2} \mathrm{yr}^{-1}\right.$ ). Seasonally, $\mathrm{CH}_{4}$ concentration in the Oubangui are relatively stable at $\sim 100 \mathrm{nM}$ at higher discharge, whereas higher $\mathrm{CH}_{4}$ concentrations are only found during low-discharge conditions. This pattern is similar to observations made in temperate and tropical river systems (De Angelis and Lilley, 1987; De Angelis and Scranton, 1993; Koné et al., 2010) and is consistent with the majority of $\mathrm{CH}_{4}$ being generated in terrestrial soils and reaching the river through baseflow. This pattern contrasts with observations in Amazonian floodplain lakes, where highest $\mathrm{CH}_{4}$ concentrations are associated with flooded conditions and floating macrophytes (e.g. Devol and Richey, 1990). On a global scale, Bastviken et al. (2011) recently argued that freshwater ecosystems are significant sources of $\mathrm{CH}_{4}$ emissions to the global continental greenhouse gas balance. While tropical rivers and lakes are typically considered to have much higher $\mathrm{CH}_{4}$ emissions than temperate or high-latitude systems, the lack of empirical data from tropical rivers is clearly evident from the data compilation by Bastviken et al. (2011), which does not contain any data from tropical river systems and assumed similar emissions per area as for temperate systems.

$\mathrm{N}_{2} \mathrm{O}$ in freshwater systems originates from either nitrification or denitrification. There is increasing interest in the role of hydroelectric reservoirs as sources of atmospheric $\mathrm{N}_{2} \mathrm{O}$ given the strong global warming potential of $\mathrm{N}_{2} \mathrm{O}$ and the potentially high $\mathrm{N}_{2} \mathrm{O}$ production rates in reservoirs, but more limited data exist for river systems (Baulch et al., 2012). This is particularly true for tropical systems where data are limited to a handful of sites in South America (compiled in Guérin et al., 2008). $\mathrm{N}_{2} \mathrm{O}$ concentrations in the Oubangui ranged between 6.2 and $9.6 \mathrm{nmoll}^{-1}$ (Fig. 8), and were lowest during low discharge conditions which is the opposite of what is typically observed in temperate rivers (Cole and Caraco, 2001b; Beaulieu et al., 2010). Surface waters were only slightly oversaturated in $\mathrm{N}_{2} \mathrm{O}(112-165 \%)$, consequently, the estimated annual $\mathrm{N}_{2} \mathrm{O}$ flux $\left(0.451 \mathrm{mmol} \mathrm{N}_{2} \mathrm{O} \mathrm{m}^{-2} \mathrm{yr}^{-1}\right)$ is low compared to the range of $<1.8$ to $36.5 \mathrm{mmol} \mathrm{N}_{2} \mathrm{O} \mathrm{m}^{-2} \mathrm{yr}^{-1}$ reported for tropical rivers by Guérin et al. (2008) and compared to data from Baulch et al. (2012) for various temperate river systems, suggesting a minor role for $\mathrm{N}_{2} \mathrm{O}$ emissions from the Oubangui. Recent synthesis of data from different temperate regions suggests that river or stream $\mathrm{N}_{2} \mathrm{O}$ 
concentrations are well correlated to nitrate levels across different systems (Beaulieu et al., 2011; Baulch et al., 2012). Preliminary $\mathrm{NO}_{3}^{-}$concentration data from the Oubangui (March-June 2011) are $<3 \mu \mathrm{mol} \mathrm{l}^{-1}$, well below the range in the Baulch et al. (2012) dataset, and thus consistent with the very low $\mathrm{N}_{2} \mathrm{O}$ fluxes we report. The seasonal pattern in $\mathrm{N}_{2} \mathrm{O}$ (Fig. 8), however, shows a marked maximum during the onset of the peak discharge, a pattern confirmed by recent measurements in 2011 (unpublished data). One possible mechanism consistent with such a maximum is that this period coincides with a replenishment of $\mathrm{NO}_{3}^{-}$inputs to deeper (anoxic) soil layers due to the onset of rains and the precipitation surplus. This $\mathrm{NO}_{3}^{-}$supply would stimulate denitrification rates in soils and hence, lead to increased $\mathrm{N}_{2} \mathrm{O}$ transport to the river network. Data for dissolved inorganic $\mathrm{N}$ currently being collected should be able to provide some insight into the drivers determining the seasonality in $\mathrm{N}_{2} \mathrm{O}$ in this pristine tropical river system. When converted to $\mathrm{CO}_{2}$ equivalents (eq) using the International Panel on Climate Change 4th Assessment (Forster et al., 2007) global warming potentials at a $20 \mathrm{yr}$ time horizon ( 72 for $\mathrm{CH}_{4}$ and 289 for $\mathrm{N}_{2} \mathrm{O}$ ), the $\mathrm{N}_{2} \mathrm{O}$ emission is minor compared to $\mathrm{CO}_{2}(<2 \%)$, which is not the case of the $\mathrm{CH}_{4}$ emission $(\sim 30 \%)$.

\subsection{Conclusions and outlook}

The initial results from a one-year monitoring study on the Oubangui River (Central African Republic) generally confirmed the downstream flux estimates for TSM and POC, which were made in the 1980's and 1990's (Coynel et al., 2005; Laraque et al., 2009). For DOC and bicarbonate, however, our higher-resolution sampling showed markedly higher and lower transport fluxes, differing by $30-35 \%$ from previous estimates. Multi-year data will be required to evaluate whether these differences reflect a long-term trend, rather than fall within the natural annual variability. Stable isotope and elemental composition (POC/PN) of particulate organic matter indicate strong seasonal differences in its composition, being predominantly terrestrial during high water stages, but with a strong phytoplankton contribution during low water stages. Similarly, DOC showed seasonal differences in its origin as determined by both $\delta^{13} \mathrm{C}$ and dissolved lignin markers, although these are more complex, and $\delta^{13} \mathrm{C}$ signatures of DOC do not follow those of POC. Estimated water-air exchange of $\mathrm{CO}_{2}, \mathrm{CH}_{4}$ and $\mathrm{N}_{2} \mathrm{O}$ are low to moderate compared to most other large tropical rivers studied so far. Ongoing sampling on the Oubangui should provide valuable additional data to assess interannual variability in element fluxes, organic matter composition, and greenhouse gas fluxes, and form an important baseline study to evaluate future natural or anthropogenic changes in this catchment, such as the proposed inter-basin water transfer scheme to Lake Chad.

\section{Supplementary material related to this article is available online at: http://www.biogeosciences.net/9/ 2045/2012/bg-9-2045-2012-supplement.pdf.}

Acknowledgements. This work was financially supported by the European Research Council (StG 240002: AFRIVAL: "African river basins: catchment-scale carbon fluxes and transformations"), a travel grant to S. B. from the Research Foundation Flanders (FWO-Vlaanderen), a National Geographic Society Research and Exploration Grant (\#8885-11) to D. P. G., and internal financial support from the University of California - Davis to J. S. We thank Marc-Vincent Commarieu for analyses of TA, Zita Kelemen for IRMS support, Michael Korntheuer (Vrije Universiteit Brussel) for his contribution to the DOC and $\delta^{13} \mathrm{C}_{\mathrm{DOC}}$ analyses, Rachael Dyda for the lignin analyses, Cristian Teodoru for redrawing Fig. 1 and constructive input on an earlier draft, and Paul Mann for pointing out a conversion error in the discussion paper. AVB is a research associate with the Fonds National de la Recherche Scientifique (FNRS). Insightful comments and suggestions by two anonymous referees significantly improved an earlier version of this manuscript.

Edited by: T. J. Battin

\section{References}

Alin, S. R., Rasera, M. F. F. L., Salimon, C. I., Richey, J. E., Holtgrieve, G. W., Krusche, A. V., and Snidvongs, A.: Physical controls on carbon dioxide transfer velocity and flux in low-gradient river systems and implications for regional carbon budgets, J. Geophys. Res.-Biogeosci., 116, GO1009, doi:10.1029/2010JG001398, 2011.

Aufdenkampe, A. K., Mayorga, E., Raymond, P. A., Melack, J. M., Doney, S. C., Alin, S. R., Aalto, R. E., and Yoo, K.: Riverine coupling of biogeochemical cycles between land, oceans, and atmosphere, Front. Ecol. Environ., 9, 53-60, doi:10.1890/100014, 2011.

Bastviken, D., Tranvik, L. J., Downing, J. A., Crill, P. M., and Enrich-Prast, A.: Freshwater methane emissions offset the continental carbon sink, Science, 331, p. 50, 2011.

Battin, T. J., Kaplan, L. A., Findlay, S., Hopkinson, C. S., Marti, E., Packman, A. I., Newbold, J. D., and Sabater, F.: Biophysical controls on organic carbon fluxes in fluvial networks, Nature Geosci., 1, 95-100, 2008.

Baulch, H. M., Schiff, S. L., Maranger, R., and Dillon, P. J.: Nitrogen enrichment and the emissons of nitrous oxide from streams, Glob. Biogeochem. Cy., 25, GB4013, doi:10.1029/2011GB004047, 2012.

Beaulieu, J. J., Shuster, W. D., and Rebholz, J. A.: Nitrous oxide emissions from a large, impounded river: The Ohio River, Environ. Sci. Technol., 44, 7527-7533, 2010.

Beaulieu, J. J., Tank, J. L., Hamilton, S. K., Wollheim, W. M., Hall, R. O., Mulholland, P. J., Peterson, B. J., Ashkenas, L. R., Cooper, L. W., Dahm, C. N., Dodds, W. K., Grimm, N. B., Johnson, S. L., McDowell, W. H., Poole, G. C., Valett, H. M., Arango, C. P., Bernot, M. J., Burgin, A. J., Crenshaw, C. L., Helton, A. M., Johnson, L. T., O’Brien, J. M., Potter, J. D., Sheibley, R. W., 
Sobota, D. J., and Thomas, S. M.., Nitrous oxide emission from denitrification in stream and river networks, P. Natl. Acad. Sci. USA, 108, 214-219, 2011.

Bird, M. I., Robinson, R. A. J., Win Oo, N., Maung Aye, M., Lu, X. X., Higgitt, D. L., Swe, A., Tun, T., Lhaing Win, S., Sandar Aye, K., Mi Mi Win, K., and Hoey, T. B.: A preliminary estimate of organic carbon transport by the Ayeyarwady (Irrawady) and Thanlwin (Salween) rivers of Myanmar, Quaternary Int., 186, 113-122, 2008.

Borges, A. V., Delille, B., Schiettecatte, L.-S., Gazeau, F., Abril, G., and Frankignoulle, M.: Gas transfer velocities of $\mathrm{CO}_{2}$ in three European estuaries (Randers Fjord, Scheldt and Thames), Limnol. Oceanogr., 49, 1630-1641, 2004.

Bouillon, S., Korntheuer, M., Baeyens, W., and Dehairs, F.: A new automated setup for stable isotope analysis of dissolved organic carbon, Limnol. Oceanogr. Methods, 4, 216-226, 2006.

Bouillon, S., Abril, G., Borges, A. V., Dehairs, F., Govers, G., Hughes, H. J., Merckx, R., Meysman, F. J. R., Nyunja, J., Osburn, C., and Middelburg, J. J.: Distribution, origin and cycling of carbon in the Tana River (Kenya): a dry season basin-scale survey from headwaters to the delta, Biogeosciences, 6, 2475-2493, doi:10.5194/bg-6-2475-2009, 2009.

Boyer, E. W., Hornberger, G. M., Bencala, K. E., and McKnight, D.: Overview of a simple model describing variations of dissolved organic carbon in an upland catchment, Ecol. Modell., 86, 183188, 1996.

Brunet, F., Dubois, K., Veizer, J., Nkoue Ndondo, G. R., Ndam Ngoupayou, J. R., Boeglin, J. L., and Probst, J. L.: Terrestrial and fluvial carbon fluxes in a tropical watershed: Nyong basin, Cameroun, Chem. Geol. 2, 563-572, 2009.

Bullen, T. D. and Kendall, C.: Tracing of weathering reactions and water flowpaths: a multi-isotope approach, in: Isotope tracers in catchment hydrology, edited by: Kendall, C. and McDonnell, J. J., Elsevier Science B.V., Amsterdam, 611-646, 1998.

Butman, D. and Raymond, P. A.: Significant efflux of carbon dioxide from streams and rivers in the United States, Nature Geosci., 4, 821-822, 2011.

Cerling, T. E., Hart, J. A., and Hart, T. B.: Stable isotope ecology in the Ituri Forest, Oecologia, 138, 5-12, 2004.

Chanat, J. G., Rice, K. C., and Hornberger, G. M.: Consistency in patterns in concentration-discharge plots, Water Resour. Res., 38, 1147, doi:10.1029/2001WR000971, 2002.

Ciais, P., Bombelli, A., Williams, M., Piao, S.L., Chave, J., Ryan, C.M., Henry, M., Brender, P., and Valentini, R.: The carbon balance of Africa: synthesis of recent research studies, Philos. Trans. Roy. Soc. A, 369, 2038-2057, 2011.

Coe, M. T., Costa, M. H., and Soares-Filho, B. S.: The influence of historical and potential future deforestation on the stream flow of the Amazon River - Land surface processes and atmospheric feedbacks, J. Hydrol., 369, 165-174, 2009.

Cole, J. J. and Caraco, N. F.: Carbon in catchments: connecting terrestrial carbon losses with aquatic metabolism, Mar. Freshwat. Res., 52, 101-110, 2001a.

Cole, J. J. and Caraco, N. F.: Emissions of nitrous oxide $\left(\mathrm{N}_{2} \mathrm{O}\right)$ from a tidal, freshwater river, the Hudson River, New York, Environ. Sci. Technol., 35, 991-996, 2001b.

Cole, J. J., Prairie, Y. T., Caraco, N. F., McDowell, W. H., Tranvik, L. J., Striegl, R. G., Duarte, C. M., Kortelainen, P., Downing, J. A., Middelburg, J. J., and Melack, J.: Plumbing the global carbon cycle: integrating inland waters into the terrestrial carbon budget, Ecosystems, 10, 171-184, 2007.

Coynel, A., Seyler, P., Etcheber, H., Meybeck, M., and Orange, D.: Spatial and seasonal dynamics of total suspended sediment and organic carbon species in the Congo River, Global Biogeochem. Cy., 19, GB4019, doi:10.1029/2004GB002335, 2005.

De Angelis, M. A. and Lilley, M. D.: Methane in surface waters of Oregon estuaries and rivers, Limnol. Oceanogr., 32, 716-722, 1987.

De Angelis, M. A. and Scranton, M. I.: Fate of methane in the Hudson river and estuary, Global Biogeochem. Cy., 7, 509-523, 2003.

Devol, A. H. and Richey, J. E.: Seasonal dynamics of methane emissions from the Amazon River floodplain to the troposphere, J. Geophys. Res., 95, 417-426, 1990.

Doctor, D. H., Kendall, C., Sebestyen, S. D., Shanley, J. B., Ohte, N., and Boyer, E. W.: Carbon isotope fractionation of dissolved inorganic carbon (DIC) due to outgassing of carbon dioxide from a headwater stream, Hydrol. Process., 22, 2410-2423, 2008.

Dosskey, M. G. and Bertsch, P. M.: Forest sources and pathways of organic matter transport to a blackwater stream: a hydrological approach, Biogeochemistry, 24, 1-19, 1994.

Duarte, C. M. and Prairie, Y. T.: Prevalence of heterotrophy and atmospheric $\mathrm{CO}_{2}$ emissions from aquatic ecosystems, Ecosystems, 8, 862-870, 2005.

Duveiller, G., Defourny, P., Desclée, B., and Mayaux, P.: Deforestation in Central Africa: estimates at regional, national and landscape levels by advanced processing of systematicallydistributed Landsat extracts, Remote Sens. Environ., 112, 19691981, 2008.

Eckard, R. S., Hernes, P. J., Bergamaschi, B. A., Stepanauskas, R., and Kendall, C.: Landscape scale controls on the vascular plant component of dissolved organic carbon across a freshwater delta, Geochim. Cosmochim. Acta, 71, 5968-5984, 2007.

Ellis, E. E., Richey, J. E., Aufdenkampe, A. K. , Krusche, A. V., Quay, P. D., Salimon, C. I., and da Cunha, H. B.: Factors controlling water-column respiration in rivers of the central and southwestern Amazon Basin, Limnol. Oceanogr., 57, 527-540, 2012.

Evans, C. and Davies, T. D.: Causes of concentration/discharge hysteresis and its potential as a tool for analysis of episode hydrochemistry, Water Resour. Res., 34, 129-137, 1998.

Forster, P., Ramaswamy, V., Artaxo, P., Berntsen, T., Betts, R., Fahey, D. W., Haywood, J., Lean, J., Lowe, D. C., Myhre, G., Nganga, J., Prinn, R., Raga, G., Schulz, M., and Van Dorland, R.: Changes in Atmospheric Constituents and in Radiative Forcing, in: Climate Change 2007: The Physical Science Basis. Contribution of Working Group I to the Fourth Assessment Report of the Intergovernmental Panel on Climate Change, edited by: Solomon, S., Qin, D., Manning, M., Chen, Z., Marquis, M., Averyt, K. B., Tignor, M., and Miller, H. L., Cambridge University Press, Cambridge, United Kingdom and New York, NY, USA, 2007.

Gadel, F., Serve, L., and Bruchet, A.: Caractérisation chimique de la fraction organique des suspensions du fleuve Congo, 97-107, Grands Bassins Fluviaux, Paris, 22-24 November 1993.

Gillikin, D. P. and Bouillon, S.: Determination of $\delta^{18} \mathrm{O}$ of water and $\delta^{13} \mathrm{C}$ of dissolved inorganic carbon using a simple modification of an elemental analyzer - isotope ratio mass spectrometer (EAIRMS): an evaluation, Rapid Comm. Mass Spectrom., 21, 1475- 
1478, 2007.

Gudasz, C., Bastviken, D., Steger, K., Premke, K., Sobek, S., and Tranvik, L. J.: Temperature-controlled organic carbon mineralization in lake sediments, Nature, 466, 478-482, 2010.

Guérin, F., Abril, G., Tremblay, A., and Delmas, R.: Nitrous oxide emissions from tropical hydroelectrical reservoirs, Geophys. Res. Lett., 35, L06404, doi:10.1029/2007GL033057, 2008.

Hedges, J. I. and Ertel, J. R.: Characterization of lignin by gas capillary chromatography of cupric oxide oxidation-products, Anal. Chem., 54, 174-178, 1982.

Hedges, J. I. and Mann, D. C.: The characterization of plant tissues by their lignin oxidation products, Geochim. Cosmochim. Acta, 43, 1803-1807, 1979.

Hedges, J. I., Clark, W. A., Quay, P. D., Richey, J. E., Devol, A. H., and Santos, U. D.: Compositions and fluxes of particulate organic material in the Amazon River, Limnol. Oceanogr., 31, 717-738, 1986.

Hellings, L., Dehairs, F., Van Damme, S., and Baeyens, W.: Dissolved inorganic carbon in a highly polluted estuary (the Scheldt), Limnol. Oceanogr., 46, 1406-1414, 2001.

Hernes, P. J., Robinson, A. C., and Aufdenkampe, A. K.: Fractionation of lignin during leaching and sorption and implications for organic matter "freshness", Geophys. Res. Lett., 34, L17401, doi:10.1029/2007GL031017, 2007.

Kohn, M. J.: Carbon isotope compositions of terrestrial C3 plants as indicators of (paleo)ecology and (paleo)climate, P. Natl. Acad. Sci., 107, 19691-19695, 2010.

Koné, Y. J. M., Abril, G., Kouadio, K. N., Delille, B., and Borges, A. V.: Seasonal variability of carbon dioxide in the rivers and lagoons of Ivory Coast (West Africa), Estuaries and Coasts, 32, 246-260, 2009.

Koné, Y. J. M., Abril, G., Delille, B., and Borges, A. V.: Seasonal variability of methane in the rivers and lagoons of Ivory Coast (West Africa), Biogeochemistry, 100, 21-37, 2010.

Lambert, T., Pierson-Wickmann, A. C., Gruau, G., Thibault, J. N., and Jaffrezic, A.: Carbon isotopes as tracers of dissolved organic carbon sources and water pathways in headwater catchments, J. Hydrol., 402, 228-238, 2011.

Laraque, A., Mahé, G., Orange, D., and Marieu, B.: Spatiotemporal variations in hydrological regime within Central Africa during the XXth century, J. Hydrol., 245, 104-117, 2001.

Laraque, A., Bricquet, J. P., Pandi, A., and Olivry, J. C.: A review of material transport by the Congo River and its tributaries, Hydrol. Process., 23, 3216-3224, 2009.

Lewis, E. and Wallace, D. W. R. : Program developed for $\mathrm{CO}_{2}$ system calculations. ORNL/CDIAC-105. Carbon Dioxide Information Analysis Center, Oak Ridge National Laboratory, US Department of Energy, Oak Ridge, Tennessee, 1998.

Ludwig, W., Probst, J. L., and Kempe, S.: Predicting the oceanic input of organic carbon by continental erosion, Global Biogeochem. Cy., 10, 23-41, 1996.

Lyons, W. B., Nezat, C. A., Carey, A. E., and Hicks, D. M.: Organic carbon flux to the ocean from high-standing islands, Geology, 30, 443-446, 2002.

Mariotti, A., Gadel, F., Giresse, P., and Kinga-Mouzeo: Carbon isotope composition and geochemistry of particulate organic matter in the Congo River (Central Africa): application to the study of Quaternary sediments off the mouth of the river, Chem. Geol., 86, 345-357, 1991.
Marotta, H., Duarte, C. M., Sobek, S., and Enrich-Past, A.: Large $\mathrm{CO}_{2}$ disequilibria in tropical lakes, Global Biogeochem. Cy., 23, GB4022, doi:10.1029/2008GB003434, 2009.

Mayorga, E., Aufdenkampe, A. K., Masiello, C. A., Krusche, A. V., Hedges, J. I., Quay, P. D., Richey, J. E., and Brown, T. A.: Young organic matter as a source of carbon dioxide outgassing from Amazonian rivers, Nature, 436, 538-541, 2005.

Meybeck, M.: Carbon, nitrogen, and phosphorus transport by world rivers, Am. J. Science 282, 401-450, 1982.

Millero, F. J.: The thermodynamics of the carbonic acid system in seawater, Geochim. Cosmochim. Acta, 43, 1651-1661, 1979.

Milliman, J. D. and Svytski, J. P. M.: Geomorphic/tectonic control of sediment discharge to the ocean: the importance of small mountaineous rivers, J. Geol., 100, 525-544, 1992.

Nkounkou, R. R. and Probst, J. L.: Hydrology and Geochemistry of the Congo River System, in: Transport of carbon and minerals in major world rivers, edited by: Degens, E. T., Kempe, S., and WeiBin, G., Mitt. Geol.-Paläont Inst. Univ. Hamburg, SCOPE/UNEP Sonderbd., 64, 483-508, 1987.

O'Connor, D. J. and Dobbins, E.: Mechanism of reaeration in natural streams, Trans. Am. Soc. Civil Engin., 123, 641-684, 1958.

Olivry, J. C. (Ed.): Opération Grands Bassins Fluviaux: premiers résultats, années 1987 à 1989, Note d'information no. 3, septembre 1989, Montpellier: ORSTOM, 124 pp., 1989.

Opsahl, S. and Benner, R.: Early diagenesis of vascular plant tissues: lignin and cutin decomposition and biogeochemical implications, Geochim. Cosmochim. Acta, 59, 4889-4904, 1995.

Orange, D., Wesselink, A. J., Mahé, G., and Feizoure, C. T.: The effects of climate changes on river baseflow and aquifer storage in Central Africa, in: Sustainability of Water Resources under increasing Uncertainty, IAHS publ. 240, 113-123, 1997.

Probst, J. L., Nkounkou, R. R., Krempp, G., Bricquet, J. P., Thiébaux, J. P., and Olivry, J. C.: Dissolved major elements exported by the Congo and the Ubangi rivers during the period 1987-1989, J. Hydrol., 135, 237-257, 1992.

Probst, J. L., Mortatti, J., and Tardy, Y.: Carbon river fluxes and weathering $\mathrm{CO}_{2}$ consumption in the Congo and Amazon river basins, Appl. Geochem., 9, 1-13, 1994.

Raymond, P. A. and Cole, J. J.: Gas exchange in rivers and estuaries: choosing a gas transfer velocity, Estuaries, 24, 312-317, 2001.

Remington, S. M., Strahm, B. D., Neu, V., Richey, J. E., and da Cunha, H. B.: The role of sorption in control of riverine dissolved organic carbon concentrations by riparian zone soils in the Amazon basin, Soil Sci., 172, 279-291, 2007.

Richey, J. E., Hedges, J. I., Devol, A. H., and Quay, P. D.: Biogeochemistry of carbon in the Amazon River, Limnol. Oceanogr., 35, 352-371, 1990.

Richey, J. E., Melack, J. M., Aufdenkampe, A. K., Ballester, V. M., and Hess, L. L.: Outgassing from Amazonian rivers and wetlands as a large tropical source of atmospheric $\mathrm{CO}_{2}$, Nature, 416, 617620, 2002.

Richey, J. E., Krusche, A. V., Johnson, M., Cunha, H. B., and Ballester, M. V.: The role of rivers in the regional carbon balance, in: Amazonia and Climate Change, LBA Synthesis Volume - Amazonia and Global Change, edited by: Keller, M., Bustamante, M., Gash, J., and Dias, P., AGU Press, 2009.

Runge, J. and Nguimalet, C. R.: Physiogeographic features of the Oubangui catchment and environmental trends reflected in discharge and floods at Bangui 1911-1999, Central African Repub- 
lic, Geomorphology, 70, 311-324, 2005.

Sanderman, J., Lohse, K. A., Baldock, J. A., and Amundson, R.: Linking soils and streams: sources and chemistry of dissolved organic matter in a small coastal watershed, Water Resour. Res., 45, W034018, doi:10.1029/2008WR006977, 2009.

Schlünz, B. and Schneider, R. R.: Transport of terrestrial organic carbon to the oceans by rivers: re-estimating flux and burial rates, Int. J. Earth Sci., 88, 599-606, 2000.

Schwartz, D.: Intérêt de la mesure du $\delta^{13} \mathrm{C}$ des sols en milieu naturel équatorial pour la connaissance des aspects pédologiques et écologiques des relations savane-forêt, Examples du Congo, Cah. Orstom Sér. Pédol., 26, 327-341, 1991.

Seyler, P. and Elbaz-Poulichet, F.: Biogeochemical control on the temporal variability of trace element concentrations in the Oubangui river (Central African Republic), J. Hydrol., 180, 319332, 1996.

Seyler, P., Coynel, A., Moreira-Turcq, P., Etcheber, H., Colas, C., Orange, D., Bricquet, J. P., Laraque, A., Guyot, J. L., Olivry, J. C., and Meybeck, M.: Organic carbon transported by the equatorial rivers: example of Congo-Zaïre and Amazon basins, 255274, edited by: Lal, R. and Roose, E., Land use, erosion and carbon dynamic, Advances in Soil Science, Lewis Publishers, CRC Press, 2005.

Spencer, R. G. M., Stubbins, A., Hernes, P. J., Baker, A., Mopper, K., Aufdenkampe, A. K., Dyda, R., Mwamba, V. L., Mangangu, A. M., Wakabanghanzi, J. N., and Six, J.: Photochemical degradation of dissolved organic matter and dissolved lignin phenols from the Congo River, J. Geophys. Res., 114, G03010, doi:10.1029/2009JG000968, 2009.

Spencer, R. G. M., Hernes, P. J., Ruf, R., Baker, A., Dyda, R. Y., Stubbins, A., and Six, J.: Temporal controls on dissolved organic matter and lignin biogeochemistry in a pristine tropical river, Democratic Republic of Congo, J. Geophys. Res., 115, G03013, doi:10.1029/2009JG001180, 2010a.

Spencer, R. G. M, Aiken, G. R., Dyda, R. Y., Butler, K. D., Bergamaschi, B. A., and Hernes, P. J.: Comparison of XAD with other dissolved lignin isolation techniques and a compilation of analytical improvements for the analysis of lignin in aquatic settings, Org. Geochem., 41, 445-453, 2010 b.
Spencer, R. G. M., Hernes, P. J., Aufdenkampe, A. K., Baker, A., Gulliver, P., Stubbins, A., Aiken, G. R., Dyda, R. Y., Butler, K. D., Mwamba, V. L., Mangangu, A. M., Wabakanghanzi, J. N., and Six, J.: An initial investigation into the organic matter biogeochemistry of the Congo River, Geochim. Cosmochim. Acta, 84, 614-627, 2012.

Stallard, R. F.: Terrestrial sedimentation and the carbon cycle: coupling weathering and erosion to carbon burial, Global Biogeochem. Cy., 12, 231-257, 1998.

Stubbins, A., Spencer, R. G. M., Chen, H., Hatcher, P. G., Mopper, K., Hernes, P. J., Mwamba, V. L., Mangangu, A. M., Wabakanghanzi, J. N., and Six, J.: Illuminated darkness: molecular signatures of Congo River dissolved organic matter and its photochemical alteration as revealed by ultrahigh precision mass spectrometry, Limnol. Oceanogr., 55, 1467-1477, 2010.

Stutter, M. I., Dunn, S. M., and Lumsdon, D. G.: Dissolved organic carbon dynamics in a UK podzolic moorland catchment: linking storm hydrochemistry, flow path analysis and sorption experiments, Biogeosciences Discuss., 9, 209-251, doi:10.5194/bgd9-209-2012, 2012.

Tan, K. S., Etchells, T., and Fox, D. R.: GUMLEAF v0.1alpha: generator for uncertainty measures and load estimates using alternative formulae. Environmetrics Australia, University of Melbourne, 2005.

Weiss, R. F.: Determinations of carbon dioxide and methane by dual catalyst flame ionization chromatography and nitrous oxide by electron capture chromatography, J. Chromatogr. Sci., 19, 611616, 1981.

Weiss, R. F. and Price, B. A.: Nitrous oxide solubility in water and seawater, Mar. Chem., 8, 347-359, 1980.

Yamamoto, S., Alcauskas, J. B., and Crozier, T. E.: Solubility of methane in distilled water and seawater, J. Chem. Eng. Data, 21, 78-80, 1976.

Zappa, C. J., Raymond, P. A., Terray, E. A., and McGillis, W. R.: Variation in surface turbulence and the gas transfer velocity over a tidal cycle in a macro-tidal estuary, Estuaries, 26, 1401-1415, 2003. 